\title{
Revisiting the Role of GSK3, A Modulator of Innate Immunity, in Idiopathic Inclusion Body Myositis
}

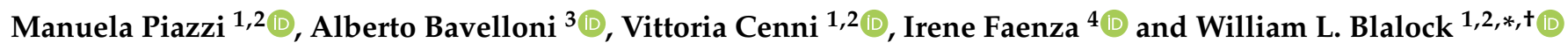 \\ 1 “Luigi Luca Cavalli-Sforza” Istituto di Genetica Molecolare-Consiglio Nazionale delle Ricerche (IGM-CNR), \\ 40136 Bologna, Italy; manuela.piazzi@cnr.it (M.P.); vittoria.cenni@cnr.it (V.C.) \\ IRCCS, Istituto Ortopedico Rizzoli, 40136 Bologna, Italy \\ 3 Laboratorio di Oncologia Sperimentale, Istituto Ortopedico Rizzoli, 40136 Bologna, Italy; \\ alberto.bavelloni@ior.it \\ 4 Dipartimento di Scienze Biomediche and Neuromotorie, Università di Bologna, 40136 Bologna, Italy; \\ irene.faenza2@unibo.it \\ * Correspondence: william.blalock@cnr.it \\ + Institute of Molecular Genetics, National Research Council of Italy, c/o Rizzoli Orthopedic Institute, Via di \\ Barbiano 1/10, 40136 Bologna, Italy.
}

\begin{abstract}
Idiopathic or sporadic inclusion body myositis (IBM) is the leading age-related (onset $>50$ years of age) autoimmune muscular pathology, resulting in significant debilitation in affected individuals. Once viewed as primarily a degenerative disorder, it is now evident that much like several other neuro-muscular degenerative disorders, IBM has a major autoinflammatory component resulting in chronic inflammation-induced muscle destruction. Thus, IBM is now considered primarily an inflammatory pathology. To date, there is no effective treatment for sporadic inclusion body myositis, and little is understood about the pathology at the molecular level, which would offer the best hopes of at least slowing down the degenerative process. Among the previously examined potential molecular players in IBM is glycogen synthase kinase (GSK)-3, whose role in promoting TAU phosphorylation and inclusion bodies in Alzheimer's disease is well known. This review looks to re-examine the role of GSK3 in IBM, not strictly as a promoter of TAU and Abeta inclusions, but as a novel player in the innate immune system, discussing some of the recent roles discovered for this well-studied kinase in inflammatory-mediated pathology.
\end{abstract}

Keywords: inflammation; degenerative disease; PKR; beta catenin; interferon; SARS-CoV2; TAU; small-molecule inhibitors

Albert McCubrey

Received: 1 October 2021

Accepted: 19 November 2021

Published: 21 November 2021

Publisher's Note: MDPI stays neutral with regard to jurisdictional claims in published maps and institutional affiliations.

\section{Introduction}

Inclusion body myositis (IBM) is a rare disorder affecting the long muscles of the arms, legs and neck, occurring in about seven individuals per million; yet, it represents one of the leading causes of muscle-related debilitation in the elderly [1]. In contrast to other autoimmune/autoinflammatory pathologies, IBM occurs prevalently in males (3:1, male:female ratio). As with Alzheimer's disease, the initial events of this pathology begin long before any overt symptoms appear, as inflammation and the degeneration of muscle tissue may initiate 10 years prior to any symptoms. While symptom onset as early as 45 years of age is not unheard of, the typical age for the onset of symptoms is over 65 [1,2]. Affected individuals usually begin noticing difficulty in climbing stairs and an increased tendency to trip, due to foot drop and / or buckling knees, leading to frequent falls and the risk of fractures. Individuals also have extreme difficulty in rising from the seated position. These physical difficulties are accompanied by atrophy of the quadriceps, wrist and finger flexor muscles so that often advanced IBM patients are confined to a wheelchair. As the disease progresses, individuals have difficulty grasping objects and eventually may lose the ability to bend their fingers and close their hand altogether. Atrophy of the neck muscles will result in the drooping of the head and dysphagia in approximately $50 \%$ of affected individuals $[1,2]$. This later often constitutes 
a major risk for regurgitation and aspiration into the lungs, resulting in aspiration-associated pneumonia and death (Figure 1).

A

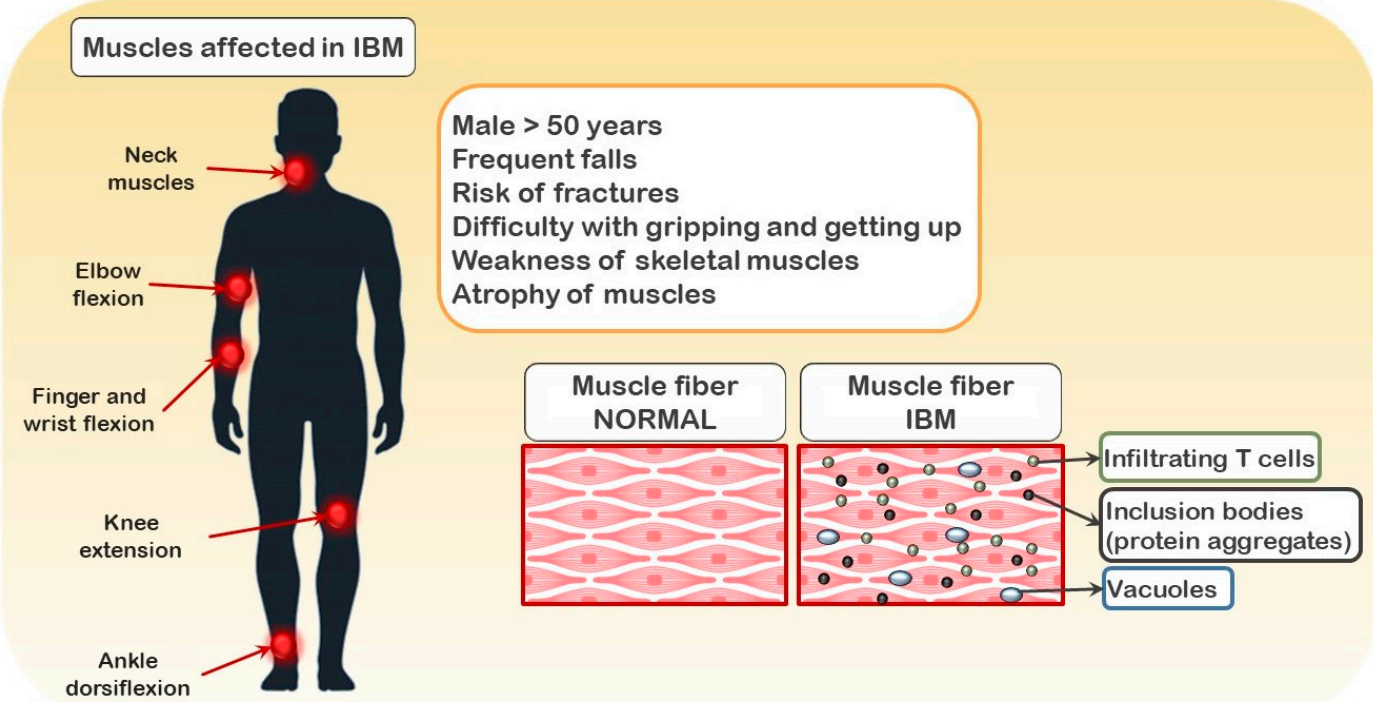

B

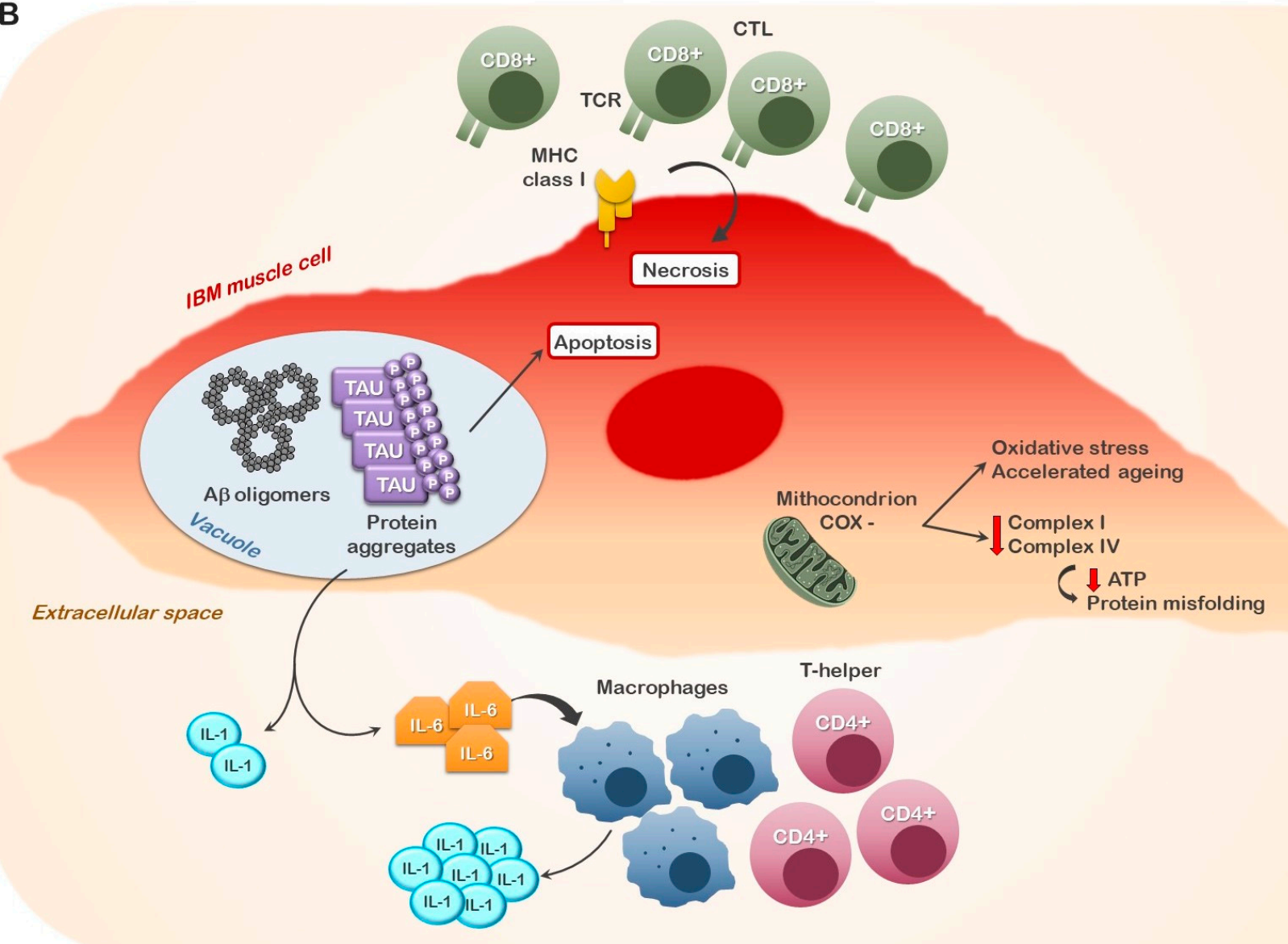

Figure 1. Physical and cellular manifestations of IBM. (A) A schematic diagram of physical and histopathological manifestations in IBM patients from early onset to late disease. (B) Schematic diagram of cellular and molecular findings in muscle biopsies from IBM patients. 
Originally defined as a degenerative pathology, inclusion body myositis, like Alzheimer's disease, has recently been reclassified as an inflammatory pathology with degenerative sequalae [1,2]. Muscle biopsies have indicated the presence of invading $\mathrm{CD}^{+}$cytotoxic T lymphocytes (CTL) and macrophages, with $\mathrm{CD}^{+} \mathrm{T}$ lymphocytes and macrophages localized to the non-necrotic muscle tissue. The presence of autoantibody to cytosolic $5^{\prime}$-nucleotidase $1 \mathrm{~A}$ (5NT1A), an enzyme involved in the regulation of adenosine levels that is highly expressed in skeletal muscle, also indicates an involvement of the humoral branch of the immune system, whereby the 5NT1A-specific antibodies produced by autoreactive B lymphocytes can contribute to the immune/inflammatory destruction of the muscle tissue. In addition, an up-regulation of the major histocompatibility complex (MHC)-I molecule is observed in affected muscle tissue fibers, likely directing the CTL-mediated response in these tissues. Rimmed vacuoles with inclusions are also a characteristic feature of IBM, although they are absent in about $20 \%$ of IBM patients, nor will all the affected muscle fibers from patients with inclusions stain for these structures [1,2]. These inclusions have been proposed to be due to an alteration in protein synthesis and processing that results in the accumulation of toxic betaamyloid (Abeta) and TAU complexes, although more than 80 proteins (including ubiquitin, HSP70, $\gamma$-tubulin, BACE 1/2, nNOS, iNOS, SOD1, IL1 $\alpha / \beta$, IL6 and GSK3, among others) have been identified and Abeta and TAU are not always present [2-4]. Not only do these complexes induce apoptotic pathways, but they have also been shown to stimulate the release of interleukin (IL)-6, an inflammatory cytokine that promotes the recruitment/activation of inflammatory macrophages and natural killer (NK) cells as part of the innate immune response, and in $\mathrm{CD}^{+}$T-helper and B-cell differentiation during adaptive immune responses [1,2]. In addition, muscle biopsies from IBM patients demonstrate an increased number of cytochrome c oxidase negative fibers, indicating alterations in mitochondrial homeostasis and cellular respiration. To this end, a study by Hedberg-Oldfors et al. has recently reported that IBM muscle tissue contains mitochondrial DNA (mtDNA) rearrangements (deletions and duplications) and nucleotide variants, with the average mtDNA copy number in IBM muscle reduced by $42 \%$ [5]. This was found to result in significant complex I and complex IV deficiency in COX-deficient fibers. Such mitochondrial defects produce pleotropic effects including reduced ATP generation, enhanced ROS production and the misfolding of proteins (Figure 1).

Therapy for inclusion body myositis in the past has included general immunomodulators/suppressors (glucocorticoids, azathioprine, methotrexate and cyclophosphamide), immunoglobulins and monoclonal antibody to mature B-cells (alemtuzumab) [6-16]. Most of the documented responses become refractory to therapy within three months, hence physical therapy and rehabilitation has remained a highly important aspect of IBM therapy. Additional therapies to target protein misfolding (arimoclomol) and lymphocyte migration (natalizumab) are currently in trial, while partial responses have been reported to date with anakinra, an IL-1 receptor antagonist, which has recently showed promise in treating severe COVID-19 patients [17-24]; again, suggesting a major role of innate immune signaling in the associated pathology (Table 1). Moreover, with regards to mitochondrial defects, the use of mitochonic acid (MA)-5 was shown to reverse several IBM-associated mitochondrial defects [25]. This review aims to revisit the role of the glycogen synthase kinase (GSK)-3 in IBM pathology both as a mediator of inclusion body formation and as a modulator of innate immune/inflammatory signaling. 
Table 1. Recent clinical trials for IBM in the USA and European Union (2000-present).

\begin{tabular}{|c|c|c|c|c|c|c|}
\hline Therapeutic & Start Date & Completion Date & Publication Date & Type of Trial & End Point & Ref. \\
\hline \multicolumn{7}{|l|}{ Pharmacological } \\
\hline ABC008 & 2021 & $\mathrm{~N} / \mathrm{A} *$ & $\mathrm{~N} / \mathrm{A}$ * & Phase I; open-label & Safety and tolerability & [26] \\
\hline Alemtuzumab & 2004 & 2007 & 2009 & Phase II & Efficacy and safety & {$[6,7]$} \\
\hline Anakinra & 2003 & 2008 & $\mathrm{~N} / \mathrm{A}$ & $\begin{array}{c}\text { Phase II/III; } \\
\text { non-randomized, } \\
\text { open-label, non- } \\
\text { placebo-controlled }\end{array}$ & Efficacy & [24] \\
\hline Anakinra & $\mathrm{N} / \mathrm{A}$ & $\mathrm{N} / \mathrm{A}$ & 2013 & $\begin{array}{l}\text { Pilot study; } \\
\text { open-label, } \\
\text { uncontrolled }\end{array}$ & Efficacy & [23] \\
\hline $\begin{array}{l}\text { Antithymocyte Ig+MTX } \\
\text { versus MTX alone }\end{array}$ & $\mathrm{N} / \mathrm{A}$ & $\mathrm{N} / \mathrm{A}$ & 2003 & $\begin{array}{l}\text { Pilot study; } \\
\text { randomized, } \\
\text { open-label, non- } \\
\text { placebo-controlled }\end{array}$ & Efficacy & [12] \\
\hline Arimoclomol & 2019 & $\mathrm{~N} / \mathrm{A}^{*}$ & $\mathrm{~N} / \mathrm{A} *$ & $\begin{array}{c}\text { Phase III (extension); } \\
\text { open-label } \\
\text { non-randomized }\end{array}$ & Efficacy & [19] \\
\hline Arimoclomol & 2019 & $\mathrm{~N} / \mathrm{A}^{*}$ & $\mathrm{~N} / \mathrm{A} *$ & $\begin{array}{c}\text { Phase III; open-label, } \\
\text { non-randomized }\end{array}$ & $\begin{array}{c}\text { Efficacy and safety of } \\
\text { early vs late start of } \\
\text { therapy }\end{array}$ & [27] \\
\hline Arimoclomol & 2018 & $\mathrm{~N} / \mathrm{A} *$ & $\mathrm{~N} / \mathrm{A} *$ & $\begin{array}{l}\text { Phase II/III; } \\
\text { randomized, } \\
\text { double-blind, } \\
\text { placebo-controlled }\end{array}$ & Efficacy & [28] \\
\hline Arimoclomol & 2017 & 2021 & $\mathrm{~N} / \mathrm{A}$ & $\begin{array}{c}\text { Phase II; randomized, } \\
\text { double-blind, } \\
\text { placebo-controlled }\end{array}$ & Efficacy & [21] \\
\hline Arimoclomol & 2009 & 2012 & 2017 & $\begin{array}{c}\text { Phase II; randomized, } \\
\text { double-blind, } \\
\text { placebo-controlled }\end{array}$ & Safety and tolerability & [22] \\
\hline Arimoclomol & 2008 & 2012 & 2017 & $\begin{array}{l}\text { Phase II/III; } \\
\text { randomized, } \\
\text { double-blind, } \\
\text { placebo-controlled }\end{array}$ & Efficacy and safety & {$[18,20]$} \\
\hline Baricitinib & 2020 & $\mathrm{~N} / \mathrm{A}^{*}$ & $\mathrm{~N} / \mathrm{A} *$ & $\begin{array}{l}\text { Phase IIa; } \\
\text { randomized, } \\
\text { controlled }\end{array}$ & $\begin{array}{l}\text { Assessment of clinical } \\
\text { response across 12- } \\
\text { and } 24 \text {-week } \\
\text { treatment arms }\end{array}$ & [29] \\
\hline Botulism & 2014 & 2018 & 2021 & Phase II; open-label & Alleviating dysphagia & {$[30]$} \\
\hline BYM338 (Bimagrumab) & 2015 & 2017 & 2018 & $\begin{array}{l}\text { Phase IIb/III; } \\
\text { randomized, } \\
\text { double-blind, } \\
\text { placebo-controlled } \\
\text { (extension) }\end{array}$ & $\begin{array}{l}\text { Efficacy, safety and } \\
\text { tolerability }\end{array}$ & [31] \\
\hline BYM338 & 2015 & 2016 & 2018 & $\begin{array}{c}\text { Phase IIb/III } \\
\text { (extension); } \\
\text { non-random, } \\
\text { double-blind, } \\
\text { placebo-controlled }\end{array}$ & $\begin{array}{l}\text { Efficacy, safety and } \\
\text { tolerability }\end{array}$ & {$[32,33]$} \\
\hline BYM338 & 2014 & 2016 & 2018 & $\begin{array}{l}\text { Phase II/III; } \\
\text { open-label }\end{array}$ & $\begin{array}{c}\text { Efficacy, safety and } \\
\text { tolerability }\end{array}$ & {$[34,35]$} \\
\hline BYM338 & 2014 & 2016 & 2017 & $\begin{array}{l}\text { Phase IIb/III; } \\
\text { randomized, } \\
\text { double-blind, } \\
\text { placebo-controlled }\end{array}$ & $\begin{array}{l}\text { Efficacy, safety and } \\
\text { tolerability }\end{array}$ & [36] \\
\hline BYM338 & 2013 & 2016 & 2017 & $\begin{array}{l}\text { Phase II/III; } \\
\text { randomized, } \\
\text { double-blind, } \\
\text { placebo-controlled }\end{array}$ & Efficacy & {$[37,38]$} \\
\hline BYM338 & 2011 & 2012 & 2014 & $\begin{array}{c}\text { Phase II; randomized, } \\
\text { double-blind, } \\
\text { placebo-controlled }\end{array}$ & $\begin{array}{l}\text { Efficacy, safety and } \\
\text { tolerability }\end{array}$ & {$[39,40]$} \\
\hline Etanercept & 2005 & 2014 & $\mathrm{~N} / \mathrm{A}$ & $\begin{array}{c}\text { Phase I; randomized, } \\
\text { double-blind, } \\
\text { placebo-controlled }\end{array}$ & Efficacy & [41] \\
\hline Etanercept & $\mathrm{N} / \mathrm{A}$ & $\mathrm{N} / \mathrm{A}$ & 2006 & $\begin{array}{c}\text { Pilot study; } \\
\text { non-randomized } \\
\text { open-label, non- } \\
\text { placebo-controlled }\end{array}$ & Efficacy & [42] \\
\hline IFN $\beta 1$ a (low-dose) & $\mathrm{N} / \mathrm{A}$ & $\mathrm{N} / \mathrm{A}$ & 2001 & $\begin{array}{l}\text { Pilot study; } \\
\text { randomized, } \\
\text { double-blind, } \\
\text { placebo-controlled }\end{array}$ & $\begin{array}{l}\text { Efficacy, safety and } \\
\text { tolerability }\end{array}$ & [43] \\
\hline
\end{tabular}


Table 1. Cont

\begin{tabular}{|c|c|c|c|c|c|c|}
\hline Therapeutic & Start Date & Completion Date & Publication Date & Type of Trial & End Point & Ref. \\
\hline IFN $\beta 1$ a (high-dose) & $\mathrm{N} / \mathrm{A}$ & $\mathrm{N} / \mathrm{A}$ & 2004 & $\begin{array}{l}\text { Pilot study; } \\
\text { randomized, } \\
\text { double-blind, } \\
\text { placebo-controlled }\end{array}$ & $\begin{array}{l}\text { Efficacy, safety and } \\
\text { tolerability }\end{array}$ & {$[44]$} \\
\hline IVIg + prednisone & $\mathrm{N} / \mathrm{A}$ & $\mathrm{N} / \mathrm{A}$ & 2001 & $\begin{array}{c}\text { Phase II; randomized, } \\
\text { double-blind, } \\
\text { placebo-controlled }\end{array}$ & Efficacy and safety & [15] \\
\hline IVIg & 1990 & 2002 & 1997, 2001 & $\begin{array}{l}\text { Phase II; double-blind, } \\
\text { placebo-controlled }\end{array}$ & Efficacy and safety & $\begin{array}{c}{[13,14,} \\
45]\end{array}$ \\
\hline Lithium & 2008 & 2009 & $\mathrm{~N} / \mathrm{A}$ & Pilot study; cohort & Efficacy & [46] \\
\hline MTX & 1996 & 2000 & 2002 & $\begin{array}{l}\text { Pilot study; } \\
\text { randomized, } \\
\text { double-blind, } \\
\text { placebo-controlled }\end{array}$ & Efficacy & [16] \\
\hline Natalizumab & 2013 & $\mathrm{~N} / \mathrm{A}$ & $\mathrm{N} / \mathrm{A}$ & $\begin{array}{l}\text { Phase I; open-label, } \\
\text { non-placebo- } \\
\text { controlled }\end{array}$ & Efficacy and safety & [47] \\
\hline Oxandrolone & $\mathrm{N} / \mathrm{A}$ & $\mathrm{N} / \mathrm{A}$ & 2002 & $\begin{array}{l}\text { Pilot study; } \\
\text { randomized, } \\
\text { double-blind, } \\
\text { placebo-controlled }\end{array}$ & Efficacy & [48] \\
\hline Phenylbutyrate & 2020 & $\mathrm{~N} / \mathrm{A}^{*}$ & $\mathrm{~N} / \mathrm{A} *$ & Phase I; open-label & $\begin{array}{c}\text { Efficacy, safety and } \\
\text { tolerability }\end{array}$ & [49] \\
\hline Pioglitazone & 2018 & 2020 & $\mathrm{~N} / \mathrm{A}$ & $\begin{array}{c}\text { Pilot study; } \\
\text { open-label, } \\
\text { non-randomized, non- } \\
\text { placebo-controlled }\end{array}$ & Efficacy & [50] \\
\hline Rapamycin & 2015 & 2018 & $\mathrm{~N} / \mathrm{A}$ & $\begin{array}{l}\text { Phase II/III; } \\
\text { randomized, } \\
\text { double-blind, } \\
\text { placebo-controlled }\end{array}$ & Efficacy & [51] \\
\hline Simvastatin & 2007 & $\mathrm{~N} / \mathrm{A}$ & $\mathrm{N} / \mathrm{A}$ & $\begin{array}{l}\text { Phase III; randomized, } \\
\text { controlled }\end{array}$ & $\begin{array}{l}\text { Efficacy, safety and } \\
\text { tolerability }\end{array}$ & [52] \\
\hline Simvastatin & 2007 & $\mathrm{~N} / \mathrm{A}$ & $\mathrm{N} / \mathrm{A}$ & $\begin{array}{l}\text { Phase III; randomized, } \\
\text { controlled, }\end{array}$ & $\begin{array}{l}\text { Efficacy, safety and } \\
\text { tolerability }\end{array}$ & [53] \\
\hline Sirolimus & $\mathrm{N} / \mathrm{A}^{*}$ & $\mathrm{~N} / \mathrm{A}^{*}$ & $\mathrm{~N} / \mathrm{A} *$ & $\begin{array}{c}\text { Phase III; randomized, } \\
\text { double-blind, } \\
\text { placebo-controlled }\end{array}$ & Efficacy & [54] \\
\hline \multicolumn{7}{|l|}{ Cell-based } \\
\hline $\begin{array}{l}\text { Adipose-derived stem } \\
\text { cells }\end{array}$ & 2021 & $\mathrm{~N} / \mathrm{A}^{*}$ & $\mathrm{~N} / \mathrm{A}$ * & $\begin{array}{l}\text { Open-label; } \\
\text { non-random }\end{array}$ & Efficacy and safety & [55] \\
\hline $\begin{array}{l}\text { Adipose-derived } \\
\text { stromal vascular } \\
\text { fraction }\end{array}$ & $\mathrm{N} / \mathrm{A} *$ & $\mathrm{~N} / \mathrm{A}^{*}$ & $\mathrm{~N} / \mathrm{A} *$ & $\begin{array}{l}\text { Phase I; open-label, } \\
\text { non-placebo- } \\
\text { controlled }\end{array}$ & $\begin{array}{l}\text { Efficacy, safety and } \\
\text { tolerability }\end{array}$ & [56] \\
\hline \multicolumn{7}{|l|}{ Gene-based } \\
\hline Follistatin & 2012 & 2017 & $\mathrm{~N} / \mathrm{A}$ & $\begin{array}{c}\text { Phase I; } \\
\text { non-randomized, } \\
\text { open-label, non- } \\
\text { placebo-controlled }\end{array}$ & Efficacy and safety & {$[57,58]$} \\
\hline
\end{tabular}

Efficacy measurements include molecular, histological/pathological and physical parameters. Abbreviations: Ig, immunoglobulin; INF $\beta 1 a$, interferon $\beta 1 \mathrm{a}$; IVIg, intravenous immunoglobulin; MTX, methotrexate; N/A, not applicable (information not available); N/A *, not applicable as study has not initiated or is ongoing.

\section{GSK3 Signaling}

In the past, the glycogen synthase kinase-3 was examined for its role in inclusion body myositis-associated muscle degeneration based on its known role in the formation of inclusion bodies and Abeta plaques in Alzheimer's disease, and the similarity of these inclusions in protein composition with those observed in IBM. The name glycogen synthase kinase- 3 in humans refers to two kinase isoforms belonging to the CMGC family of serine/threonine kinases that are encoded on separate genes located at Ch.19q13.2 (the $\alpha$-isoform; a 51-kDa protein) and Ch.3q13.3 (the $\beta$-isoform; a 47-kDa protein). Both isoforms are ubiquitously expressed at the protein level in different tissues, with the greatest expression of GSK $3 \alpha$ being observed in the brain, lung, gastrointestinal tract, pancreas, testis, ovaries and bone marrow; while GSK3 $\beta$ expression is most highly expressed in the brain tissue, but is also found in a number of other tissues [59-61]. Interestingly for an enzyme closely linked to glucose metabolism, only the $\alpha$-isoform is significantly observed in muscle tissue, according to the Human Protein Atlas [61]. Within the cell, GSK3 $\alpha$ localizes to the nucleus, 
cytosol and mitochondria, while GSK3 $\beta$ localizes mainly to the nucleus, cytosol or cell membrane. The GSK3 isoforms are 98\% identical but maintain significant diversity in both the amino- and carboxyl-termini. In addition, GSK3 $\alpha$ also contains an extension of the glycine-rich sequence in the amino terminus, which likely results in the differing sub-cellular localization and substrate preferences observed between these kinases $[59,60]$. GSK $3 \alpha / \beta$ phosphorylate and regulate proteins involved in glucose homeostasis (AKT1, IRS2), transcription ( $\beta$-catenin, C/EBP $\alpha / \beta, \mathrm{CREB}, \mathrm{c}-J U N$, c-MYC, STAT), microtubule assembly (ACF7, ADD2, MAP2, TAU), apoptosis (BAX, BCL3, BCL-XL, XIAP), inflammation (IKK $\gamma$, IL1-RL1, IL-17RA, IRF1, NF-KB, SMAD, TRAF6), cell cycle (CDC25A, p21 CIP1, p53) and translation (4E-BP, eIF2B $\varepsilon$, EIF6) [62]. GSK3 $\alpha / \beta$-mediated phosphorylation is dependent on a priming phosphorylation carried-out by a secondary kinase at a site four amino acids C-ter to the GSK3 $\alpha / \beta$-dependent site $[59,60]$. Thus, in theory, the phosphorylation of a series of GSK $3 \alpha / \beta$-dependent sites on a substrate protein (e.g., $\beta$-catenin) would occur sequentially from $\mathrm{C}$-ter to $\mathrm{N}$-ter, following the initial priming phosphorylation mediated by a secondary kinase. With few exceptions, GSK3 $\alpha / \beta$-mediated phosphorylations have a negative regulatory effect on the substrate [60].

The regulation of GSK3 kinase activity is through the phosphorylation of a key tyrosine residue in the catalytic domain (Y279 or Y216 in GSK3 $\alpha$ or $\beta$, respectively), which may be carried-out by upstream tyrosine kinases such as FYN, SRC, the proline-rich tyrosine kinase, PYK2 and even the dual Ser/Thr and Tyr kinase MEK1, thereby enhancing GSK3 catalytic activity. In addition, as the GSK3 kinases are constitutively active at a basal level, a rare autophosphorylation at these sites has also been described [63-66]. The inactivation of GSK3, in contrast, requires the phosphorylation of a serine residue within the glycine-rich region of the kinase (S21 in GSK3 $\alpha$ and S9 in GSK3 $\beta$ ), causing a conformational change in the protein, thus blocking access of the substrate to the active site. Phosphorylation at this site can occur via AKT1, Aurora kinase, diverse ribosomal S6 kinases (p70S6K1/2, p90RSK and RSK2), serine/threonine protein kinase (SGK)-3, protein kinase A (PKA), inhibitor kappa B kinase (IKK)- $\varepsilon$ and various protein kinase C (PKC) isoforms (https://www. phosphosite.org/siteAction.action?id=4590 (accessed on 17 November 2021); https: / / www. phosphosite.org/siteAction.action?id=6534 (accessed on 17 November 2021) $[60,62,67]$ ). Moreover, a number of additional phosphorylation sites have been demonstrated to be important for GSK3 regulation (Table 2).

Table 2. A list of GSK $3 \alpha / \beta$ post-translational modification sites with known modifiers, consequences or significant homology between isoforms.

\begin{tabular}{|c|c|c|c|}
\hline GSK3 $\alpha$ & GSK3 $\beta$ & Modification & Enzyme or Treatment/Significance \\
\hline T19 & - & phosphorylation & Unknown; induces inhibition of kinase activity \\
\hline S21 & S9 & phosphorylation & $\begin{array}{l}\text { AKT/PKC/RSK/Aurora (GSK3 } \beta \text { only); induces inhibition of } \\
\text { kinase activity }\end{array}$ \\
\hline S41 & - & phosphorylation & MG132 withdrawal; unknown \\
\hline S52 & - & phosphorylation & MEK inhibition; unknown \\
\hline S63 & - & phosphorylation & MEK inhibition; unknown \\
\hline- & S21 & phosphorylation & 5, 7-dihydroxyflavone (chrysin); apoptosis induced \\
\hline- & S25 & phosphorylation & MG132 withdrawal; unknown \\
\hline S97 & S35 & phosphorylation & MG132 withdrawal; unknown \\
\hline- & T43 & phosphorylation & p38 $\alpha /$ ERK; activation of enzymatic activity \\
\hline- & Y56 & phosphorylation & MET; activation of enzymatic activity \\
\hline Y134 & Y71 & phosphorylation & Unknown; unknown \\
\hline- & K86 & ubiquitination & Unknown; activation of enzymatic activity \\
\hline- & S147 & phosphorylation & PKC $\zeta$; activation of enzymatic activity \\
\hline K246 & K183 & ubiquitination & Unknown; degradation of protein \\
\hline K260 & K197 & ubiquitination & Unknown; inhibition of enzymatic activity \\
\hline K268 & K205 & ubiquitination; acetylation & siRNA; subcellular localization and phosphorylation altered \\
\hline S278 & S215 & phosphorylation & IL3, serum; unknown \\
\hline Y279 & Y216 & phosphorylation & GSK3/MEK; activation of enzymatic activity \\
\hline S282 & S219 & phosphorylation & MEK inhibition; unknown \\
\hline
\end{tabular}


Table 2. Cont.

\begin{tabular}{|llll|}
\hline GSK3 $\alpha$ & GSK3 $\beta$ & \multicolumn{1}{c|}{ Modification } & \multicolumn{1}{c}{ Enzyme or Treatment/Significance } \\
Y284 & Y221 & phosphorylation & Unknown; unknown \\
Y285 & Y222 & phosphorylation & Unknown; unknown \\
K355 & K292 & ubiquitination; sumoylation & Unknown; unknown \\
- & S389 & phosphorylation & p38 $\alpha$; intracellular localization \\
- & T390 & phosphorylation & p38 $\alpha$; activation of enzymatic activity \\
- & T392 & phosphorylation & Nocodazole; unknown \\
- & T402 & phosphorylation & Nocodazole; unknown \\
- & T420 & phosphorylation & MG132 withdrawal; unknown \\
\hline
\end{tabular}

All information was retrieved from the PhosphoSitePlus database under the sites table page at the following: https://www.phosphosite. org $/$ proteinAction. action?id=603\&showAllSites=true and https: $/ /$ www.phosphosite.org $/$ proteinAction . action?id=604\&showAllSite=true (accessed on 17 November 2021). Ref. [62]. Homologous post-translationally modified sites were aligned using a comparative NCBI Protein Blast search.

\section{GSK3 and Inclusions}

The microtubule-associated protein TAU, the product of the mapt gene, serves the purpose of facilitating microtubule assembly, thereby linking the cytoskeletal microtubule components to the plasma membrane. At least nine different isoforms of TAU are produced through alternative splicing, with some isoforms restricted to a specific developmental stage and/or tissue [68]. The largest isoform, PNS-TAU, is expressed in the peripheral nervous system, whereas the other isoforms are found in the central nervous system, kidney and urinary tract tissues, female tissues, muscle and adipose/soft tissues. TAU is a highly modified protein that is a target of at least twelve different kinases, including GSK $3 \alpha / \beta$ [68-72]. The analysis of the PhosphoSitePlus database indicates that while GSK3 $\alpha$ has been shown to phosphorylate a number of TAU isoforms (isoforms 2, 5, 6 and 8), GSK3 $\beta$ has been demonstrated to phosphorylate isoform 8 (Table 3) [62,73-87]. The majority of the sites phosphorylated by the GSK3 kinases lie near to or within the C-ter tubulin binding repeat (aa 560-690), with the exception of two sites phosphorylated by GSK3 $\beta$ (S46 and T50). In general, the phosphorylation of these residues results in the detachment of TAU from the microtubule complex and disassembly. In normal tissue development, the assembly-disassembly process is regulated through an interplay between the O-GlcNacylation, phosphorylation and dephosphorylation of these sites. As phosphorylation and O-GlcNacylation are mutually exclusive post-translational modifications on a specific site, the interplay between these modifications either leads to O-GlcNacylation with consequential microtubule assembly or phosphorylation resulting in microtubule disassembly. In multiple degenerative diseases such as AD and IBM, the loss of O-GlcNacylation has been associated with the hyperphosphorylation of TAU [68,69]. These hyperphosphorylated TAU molecules become seeds for the development of filamentous tangles which lead to the activation of the unfolded protein response (UPR), through the stress activation of the PKR-like endoplasmic reticulum kinase, PERK, and the NLRP3 inflammasome, through the activation of the stress/inflammatory kinase PKR, resulting in enhanced IL-1 $\beta$ synthesis, progressive inflammation, cell death and disease (Figure 2) [88-94]. 
Table 3. Sites of GSK3 $\alpha / \beta$-mediated phosphorylation in TAU (MAPT).

\begin{tabular}{|c|c|c|c|c|}
\hline Isoform & Phosphorylation Site & & Ref. & \\
\hline & & GSK3 $\alpha$ & GSK3 $\beta$ & \\
\hline TAU isoform 2 & S307 (S713) & $X$ & & [73] \\
\hline TAU isoform 2 & S315 (S721) & $X$ & & [73] \\
\hline TAU isoform 5 & T181 (T498) & $x$ & & [74] \\
\hline TAU isoform 5 & S184 (S501) & $\mathrm{X}$ & & [74] \\
\hline TAU isoform 5 & S195 (S512) & $\mathrm{X}$ & & [74] \\
\hline TAU isoform 5 & S198 (S515) & $\mathrm{X}$ & & [74] \\
\hline TAU isoform 5 & S199 (S516) & $X$ & & [74] \\
\hline TAU isoform 5 & S202 (S519) & $\mathbf{X}$ & & {$[74]$} \\
\hline TAU isoform 5 & T205 (T522) & $x$ & & [74] \\
\hline TAU isoform 5 & T231 (T548) & $X$ & & {$[73,74]$} \\
\hline TAU isoform 5 & S235 (S552) & $X$ & & {$[73,74]$} \\
\hline TAU isoform 5 & S262 (S575) & $X$ & & [74] \\
\hline TAU isoform 5 & S325 (S673) & $\mathrm{X}$ & & [74] \\
\hline TAU isoform 5 & S365 (S713) & $\mathrm{X}$ & & [73] \\
\hline TAU isoform 5 & S369 (S717) & $X$ & & [74] \\
\hline TAU isoform 5 & S373 (S721) & $x$ & & {$[73,74]$} \\
\hline TAU isoform 6 & T173 (T548) & $X$ & & {$[73,75]$} \\
\hline TAU isoform 6 & S177 (S552) & $\mathrm{X}$ & & [73] \\
\hline TAU isoform 6 & S338 (S713) & $x$ & & {$[73,75]$} \\
\hline TAU isoform 6 & S346 (S721) & $X$ & & {$[73,75]$} \\
\hline TAU isoform 8 & S46 (S46) & & $x$ & [76] \\
\hline TAU isoform 8 & T50 (T50) & & $X$ & [76] \\
\hline TAU isoform 8 & T153 (T470) & & $\mathrm{X}$ & [77] \\
\hline TAU isoform 8 & T175 (T492) & & $X$ & [77] \\
\hline TAU isoform 8 & T181 (T498) & & $X$ & [78-80] \\
\hline TAU isoform 8 & S195 (S512) & & $\mathrm{X}$ & [81] \\
\hline TAU isoform 8 & S199 (S516) & & $X$ & {$[81,82]$} \\
\hline TAU isoform 8 & S202 (S519) & & $X$ & {$[78,82]$} \\
\hline TAU isoform 8 & T205 (T522) & & $\mathrm{X}$ & {$[81,82]$} \\
\hline TAU isoform 8 & S210 (S527) & & $X$ & [81] \\
\hline TAU isoform 8 & T212 (T529) & & $\mathrm{X}$ & {$[78,82]$} \\
\hline TAU isoform 8 & S214 (S531) & & $X$ & {$[79,81]$} \\
\hline TAU isoform 8 & T217 (T534) & & $X$ & {$[78,82]$} \\
\hline TAU isoform 8 & T231 (T548) & $X$ & $\mathrm{X}$ & {$[73,78,83-85]$} \\
\hline TAU isoform 8 & S235 (S552) & $X$ & $\mathrm{X}$ & {$[73,77,84]$} \\
\hline TAU isoform 8 & S262 (S579) & $X$ & $X$ & {$[79,82-84,86]$} \\
\hline TAU isoform 8 & S396 (S713) & $x$ & $X$ & {$[73,81,82]$} \\
\hline TAU isoform 8 & S400 (S717) & & $X$ & {$[81,87]$} \\
\hline TAU isoform 8 & S404 (S721) & $\mathrm{X}$ & $x$ & {$[73,81,82]$} \\
\hline TAU isoform 8 & S409 (S726) & & $X$ & [79] \\
\hline TAU isoform 8 & S422 (S739) & & $X$ & [79] \\
\hline
\end{tabular}

Phosphorylation sites in parenthesis are indicative of the position in the fully encoded TAU protein. Information was obtained from the PhosphoSitePlus database under the substrate page at the following https: / / www.phosphosite.org/substrateSearchViewAction.action?id=987\&type=Protein (accessed on 17 November 2021); https:// www.phosphosite.org/ substrateSearchViewAction.action?id=988\&type=Protein (accessed on 17 November 2021). Ref. [62]. 


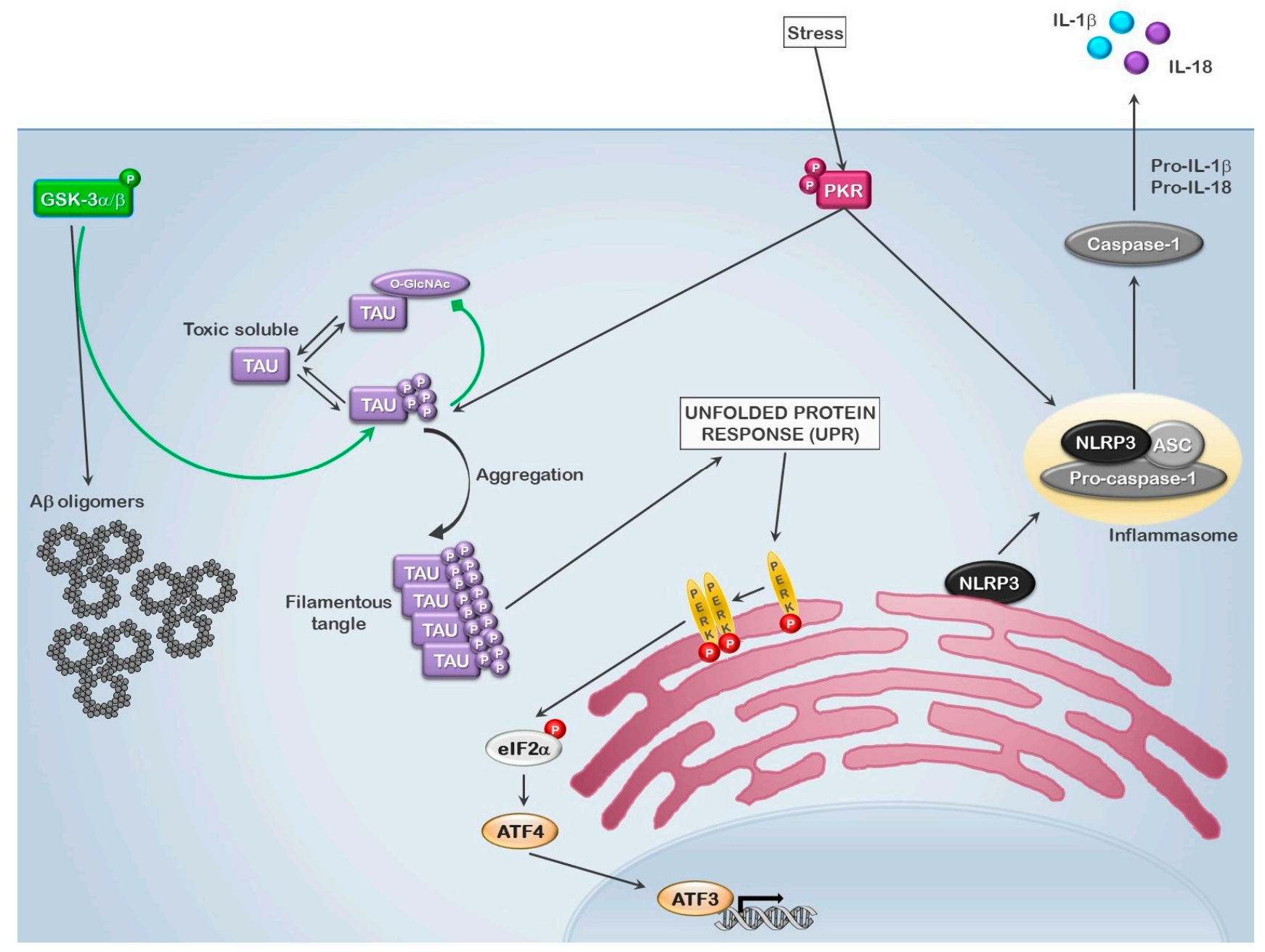

Figure 2. Role of GSK3 in the formation of inclusion bodies. GSK3 activation leads to enhanced Abeta accumulation and hyperphosphorylation of TAU, leading to the formation of inclusion bodies, resulting in cellular stress and the activation of the unfolded protein response (UPR). In conjunction with the innate immune/stress activated kinase PKR and the UPR associated kinase PERK, this leads to the phosphorylation of eIF2 $\alpha$, the inhibition of general translation, IRES-mediated translation of ATF4 and the activation of the NLRP3 inflammasome, thus promoting IL-1 $\beta$ release and cell death.

The link between GSK3, amyloid precursor protein (APP)-derived Abeta and TAU in $\mathrm{AD}$ has been well described $[95,96]$. Interestingly, a similar scenario has been proposed in IBM. While not all muscle fibers contain fibrillary inclusions, a significant number do, making this characteristic a hallmark of the IBM pathology $[2,97,98]$. Early studies have demonstrated that the overexpression of Abeta in human skeletal muscle fibers and transgenic mice could induce GSK3 $\beta$ activation and the enhanced phosphorylation of TAU, leading to inclusion body myositis-like pathological outcomes, including both inclusion bodies and inflammatory infiltrates in mice $[99,100]$. Of significant interest was the finding by Kitazawa et al. in a mouse model of IBM (double transgenic MCK-APP/PS1 C57BL/ 6 mice) that acute (single intramuscular administration) and chronic (intraperitoneal administration once per week for 12 weeks) inflammatory stimulation (lipopolysaccharide; LPS) resulted in enhanced $\mathrm{CD} 8^{+} \mathrm{T}$ lymphocyte infiltrates in the muscle tissue, increased presence of pro-inflammatory cytokines (specifically IL- $1 \beta$ and TNF $\alpha$ ), increased APP expression levels, enhanced GSK3 $\beta$ activation and enhanced TAU phosphorylation, while enhanced Abeta expression was specific to chronic inflammation [100]. Moreover, these authors demonstrated in the $\mathrm{C} 2 \mathrm{C} 12$ mouse myoblast cell line that the inflammatory cytokines IL-1 $\beta$, IL- 6 and TNF $\alpha$ could activate GSK3 $\beta$, suggesting that IBM is likely initiated by a chronic inflammatory/cellular stress insult. Additional studies have also recently linked 
the altered GSK3 $\beta$ activity to deficits in protein degradation by the autophagosome. In contrast to the role of GSK $3 \beta$ in Abeta and hyperphosphorylated TAU-mediated toxicity, where the activation of GSK3 is pathological, Nicot et al. demonstrated that the lack of GSK3 catalytic activity directed toward T586 of the neighbor of BRCA1 (NBR1) caused the increased protein aggregation and stabilization of ubiquitinated proteins, and found that NBR1 phosphorylation on T586 is reduced in IBM [101]. While the authors reported that the phosphorylation of T586 had no appreciable effect on the ability of NBR1 to interact with partner proteins necessary for autophagy, such as SQSTM1, UB, LC3B and GABARAP, it did interfere with NBR1 aggregate interaction and formation and the selective autophagy of ubiquitinated proteins. Their conclusions suggest that GSK3-dependent phosphorylation at T586 may serve as a switch between selective and non-selective autophagy under normal growth conditions that would be primarily regulated by flux through the PI3K-AKT-mTOR pathway. In disease conditions such as sIBM, the lack of NBR1 T586 phosphorylation, for reasons not directly associated to the presence (or absence) of active GSK3 in the affected tissue, enhances aggregate formation, overloading the autophagic system and promoting inclusions [101]. Interestingly, while GSK3 $\beta$ activation was the focus of many of these early analyses, according to the Human Protein Atlas, normal human muscle tissue expresses GSK3 $\beta$ mRNA but not the encoded protein. In contrast, both GSK $3 \alpha$ mRNA and the encoded protein are known to be expressed in normal human muscle tissue (https://www.proteinatlas.org/ENSG00000105723-GSK3A (accessed on 25 September 2021); https: / /www.proteinatlas.org/ENSG00000082701-GSK3B (accessed on 25 September 2021) [61]). This begs the question whether the original reports of the activation of GSK3 in IBM were erroneously associated with the $\beta$-isoform when GSK3 $\alpha$ is actually the main isoform involved, or whether the protein expression of GSK3 $\beta$ is induced in IBM muscle fibers. One might suggest the latter, but in the studies cited, GSK3 $\beta$ was also observed in control muscle biopsies. As many of these studies used antibodies and Western blotting to distinguish proteins that are $98 \%$ identical at the amino acid level, some ambiguity in the isoform detected would be expected. Additional analyses are necessary to sort out which GSK3 isoform is mainly involved.

\section{GSK3 as a Mediator of Innate Immunity in Inclusion Body Myositis}

The prior studies involving GSK3 in IBM mentioned above were aimed at defining the role of GSK $3 \beta$ in what was considered primarily a degenerative disorder at the time. While there is still debate as to whether to consider IBM primarily an autoinflammatory pathology, a degenerative disease or both, it is very interesting to note the similarities between IBM and Alzheimer's disease. There is a close association between Alzheimer's disease and viral infection (HIV, herpes), including recent evidence demonstrating that SARS-CoV2 patients present elevated Alzheimer's-associated markers and that SARS-CoV2 accelerated AD progression in patients; interestingly, IBM was first described as a viral-associated polymyositis [102-104]. Together, these findings might point to an initial inflammatory cause of both pathologies deriving from any number of infectious or environmental factors, most likely in the background of particular genetic features.

The innate immune system is not only an organism's first line of defense against infectious agents in the environment (viruses, bacteria), but also environmental stresses (toxins, pollutants) and internal stresses resulting from inherited mutations, oxidative stress, age-related DNA and protein damage, as well as physical and mechanical stresses. The acute activation of innate immune signaling has the scope of limiting cell and tissue damage, promoting cell/tissue repair and impeding the propagation of the stress and any damaged cells and macromolecules (DNA, protein, lipids) [105]. The chronic activation of innate immune signaling, on the other hand, leads to chronic inflammation and stress, which has been shown to promote tissue damage and cell death and/or changes in the cell, including the propensity to accumulate mutations, which is likely an evolutionary backdoor to randomly achieve stress adaptation, but equally capable of resulting in disease $[105,106]$. The acute activation will induce a stress/inflammatory response, which may or may not 
involve the activation of an acquired or adaptive immune response; while, in contrast, the chronic activation of innate immune pathways will invariantly promote the activation of an acquired cell-mediated response that can also take the form of autoimmunity [107].

Patients with inclusion body myositis are known to present with elevated pro-inflammatoryassociated cytokines and proteins in the affected tissues. In addition, as stated above, many reports have implicated a role for elevated GSK3 activity in IBM. The involvement of GSK3 in regulating the immune response has been known for some time, and its activation status is linked to both pro- and anti-inflammatory immune signaling [108,109]. The suppression of GSK3 $\beta$ expression or activity was reported to drastically reduce the TLR3-mediated production of inflammatory cytokines [110]. Likewise, GSK3 $\beta$ KO mice were reported to have diminished pro-inflammatory but enhanced anti-inflammatory responses in their livers [111]. Bone marrowderived macrophages from these mice showed decreased TNF $\alpha$ transcription and increased IL-10 synthesis upon Toll-like receptor (TLR)-4 stimulation [111]. Interestingly, the reported effects of the loss of GSK3 $\beta$ in these mice were partially traced to the enhanced activation of AMPK in the absence of GSK3. This is highly intriguing, as AMPK is a major regulator of the STING-mediated antiviral pathway, which is involved in the activation of interferon response factor (IRF)-3 and 7 and the induction of type I interferon (IFN) synthesis [112].

Recent evidence suggests that much of the immunoregulatory role of GSK3 lies in its ability to influence type I IFN signaling [113-117]. GSK3 $\alpha / \beta$ are both major regulators of the WNT/ $\beta$-catenin signaling pathway $[60,118]$. The activation of this pathway is controlled both through the cytoplasmic sequestering of $\beta$-catenin by AXIN and its ubiquitination by TrCP1 and subsequent proteosome-mediated degradation. The AXIN polymers and GSK3 form a $\beta$-catenin destruction complex, whereby the AXIN polymers form a scaffold for the association of $\beta$-catenin and GSK3. In turn, the phosphorylation of $\beta$-catenin by GSK3 promotes its interaction with TrCP1, facilitating its degradation. In the presence of WNT, the AXIN scaffold is destabilized and $\beta$-catenin is released from the destruction complex, finally translocating to the nucleus where it stimulates the synthesis of a number of genes, including interferon response factor (IRF)-3 [113]. Not surprisingly, the overexpression of $\beta$-catenin or the inhibition of GSK3 by $\mathrm{LiCl}$ was reported to suppress bovine parainfluenza virus type 3 replication [114]. During productive infection, BIV promoted the degradation of $\beta$-catenin through the GSK3 $\beta$-mediated proteasome pathway, suggesting a proviral role for GSK3 in promoting productive viral infection, likely through the inhibition of IFN production. Thus, in hindsight, it is rather interesting, even though no significant improvements were reported during the 6-month pilot study, that one of the first tested therapies for sIBM was IFN $\beta 1$.

The loss or the reduction of GSK3 is not limited to IRF3 activation and type I IFN synthesis, but also results in the reduced expression of inflammatory cytokines. Li et al. reported that miR-709, which targets the GSK3 $\beta$ transcript, is up-regulated following the stimulation of RAW264.7 macrophage cells with LPS. The up-regulation of miR-709 enhanced the levels of $\beta$-catenin while reducing the expression of inflammatory cytokines IL-1 $\beta$, IL-6 and TNF $\alpha$, all known to be up-regulated in IBM patients [119]. Li et al. did not discuss the involvement of type I IFNs in this effect, but one might expect such a scenario, as type I interferons tend to promote an anti-inflammatory environment.

The regulation of IFN synthesis is not limited only to $\beta$-catenin levels and nuclear translocation, as GSK $3 \alpha / \beta$ has also been shown to directly phosphorylate the prolinelinker region of IRF3, inhibiting IRF3-dependent IFN production [117]. Moreover, Qin et al. demonstrated that the tripartite motif 9 (TRIM9) short isoform undergoes autopolyubiquitination on Lys-63, serving as a platform to link GSK3 $\beta$ to TANK-binding kinase 1 (TBK1) [115]. Associated with TRIM9, GSK3 $\beta$ was shown to enhance TBK1 oligomerization and activation in a kinase-independent manner; thus, GSK3 activity did not influence the observed effects on TBK1. This interaction is of substantial importance, as TBK1 is the central kinase which figures into IRF3 transcriptional activation. It becomes activated in response to the activation of the DNA sensor CGAS and the RNA sensors RIG-I and MDA5, through the interaction of their respective downstream effectors, STING 
(cGAS) and MAVS (RIG-1 and MDA5). In this study, TRIM9 expression was also observed to enhance IRF3 transcriptional activation and IFN synthesis while inhibiting the expression of the pro-inflammatory cytokines, TNF $\alpha$ and IL-6, which is similar to that reported in RAW264.7 cells [115,119].

In contrast to IRF3 and type I IFN observed following GSK3 inhibition, GSK3 activity is associated with enhanced type II IFN (IFN $\gamma$ ) signaling, the enhanced synthesis of other pro-inflammatory cytokines and the repression of IL-10 synthesis [120-123]. Such GSK3promoted conditions are observed in IBM tissues, where low IL-10 expression and enhanced IL-1, IL- 6 and IFN $\gamma$ drive the generation of a pro-inflammatory environment containing inflammatory macrophages and $\mathrm{CD} 8^{+} \mathrm{CTLs}$ that promote tissue damage.

These findings seem to indicate that GSK3 has a negative influence on type I IFN production while stimulating an inflammatory state, thus making GSK3 a potential target in IBM, not only at the level of degeneration, but also of inflammation (Figure 3). One potential caveat of this therapeutic potential may lie in observations obtained with SARS-CoV2. Like bovine parainfluenza virus infection, GSK3 activity is associated with enhanced SARSCoV2 infection and viral production, in part due to the GSK3-mediated phosphorylation of the SARS-CoV2 nucleocapsid $(\mathrm{N})$ protein, but also likely through reducing and delaying type I IFN production, resulting in enhanced pro-inflammatory cytokine expression, as observed in patients with more severe COVID-19 [124]. In a recent commentary, Dr. Christopher Rudd suggests that the use of small molecule inhibitors (SMIs) to GSK3 for SARS-CoV2 treatment may be beneficial for two reasons: the first being the inhibition of viral replication, and the second being its immunomodulatory effects [125]. However, this immuno-modulating effect to which Dr. Rudd refers is centered on enhanced CD8 ${ }^{+} \mathrm{T}$ lymphocyte (CTL) and NK cell effector functions, two factors implicated in muscle tissue destruction in IBM, and not on the pro-inflammatory cytokine storm. That said, it is quite probable that reducing the chronic inflammatory conditions in the affected tissue can bring into check the immune cell-mediated response, a process which normally occurs during the resolution phase of the immune response. 


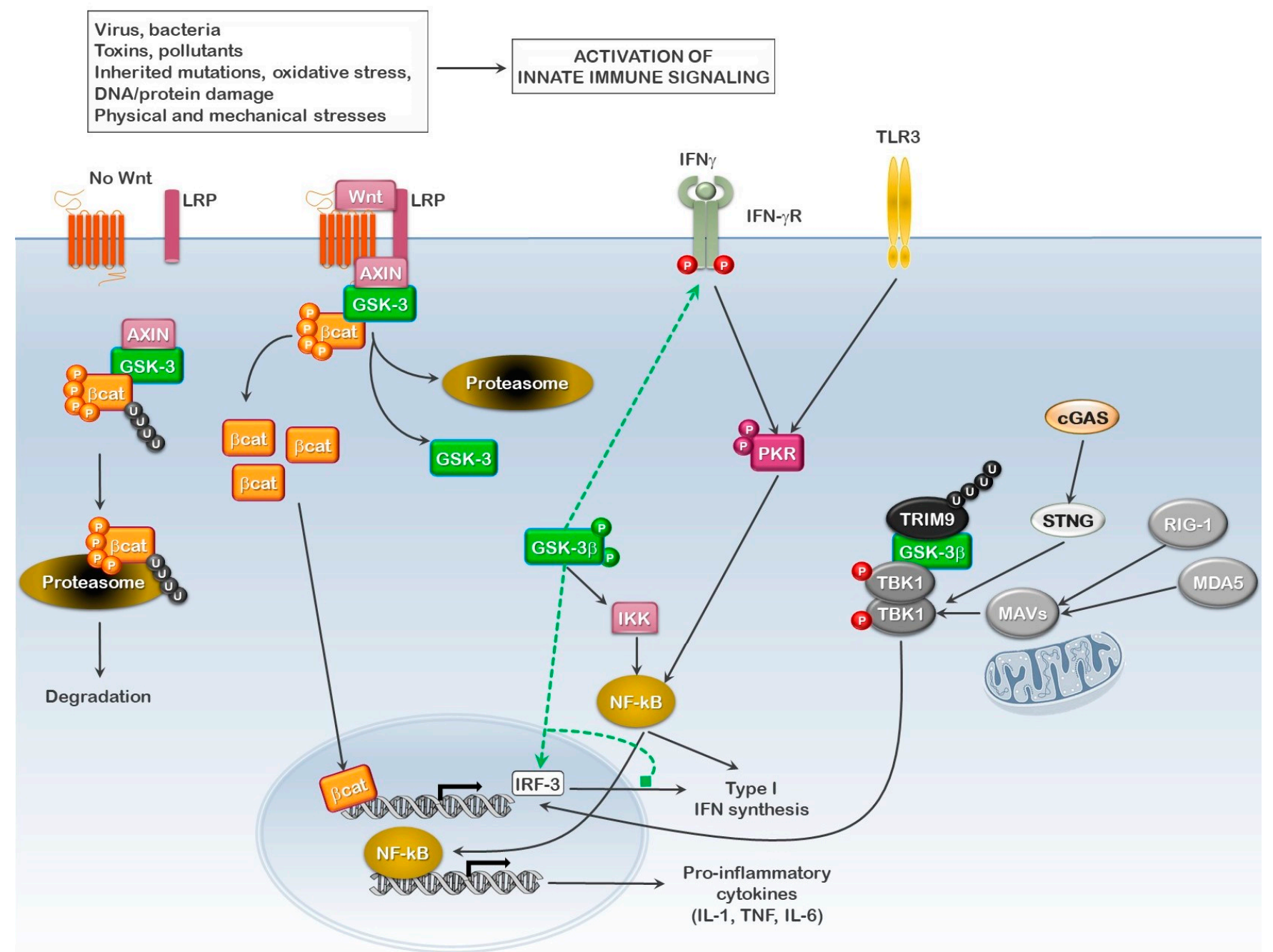

Figure 3. Role of GSK3 in regulating innate immune signaling. Synthesis of type I interferons requires both interferon response factor (IRF), NF- $\mathrm{kB}$ activation and nuclear localization, and the subsequent binding to their respective elements in the IFN $\alpha / \beta$ promoter. In the presence of active GSK3, $\beta$-catenin is phosphorylated and degraded, thus inhibiting the synthesis of IRF-3, while NF-KB activation and nuclear localization are stimulated, thus favoring the synthesis of pro-inflammatory cytokines. In addition, active GSK3 also stabilizes the IFN $\gamma$ receptor (IFN $\gamma \mathrm{R}$ ), thus enhancing IFN $\gamma$ pro-inflammatory signaling. In the absence of GSK3 activity, $\beta$-catenin is released upon stimulation, translocates to the nucleus and promotes the synthesis of IRF-3. Signaling mediated by the pattern recognition receptor (PRR) proteins (RIG-I, MDA5, cGAS) promotes IRF-3 activation and nuclear localization, while the activation of PKR results in p65 NF- $\mathrm{BB}$ phosphorylation, activation and nuclear translocation where active p $65 \mathrm{NF}-\kappa \mathrm{B}$ either synergizes with signaling mediated by the other PRRs to aid in the synthesis of type I IFN (GSK3 inactive) or induces the synthesis of pro-inflammatory cytokines (GSK3 active).

\section{Conclusions}

In the past, the role of GSK3 in IBM was assessed primarily for its role in the formation of Abeta-TAU inclusions. Recent findings now tightly link GSK3 with antiviral/innate immune signaling regulation, whereby GSK3 activity inhibits the type I IFN response but promotes pro-inflammatory signaling. This is interesting, as the role of GSK3 in pathology is often found associated with that of the innate immune/antiviral/stress response kinase PKR, which is both an inducer of type I IFNs as well as an IFN response gene known to be involved in neurodegenerative diseases (Alzheimer's disease, Huntington's chorea and Creutzfeldt-Jakob disease), muscular degenerative disease (myotonic dystrophy) and cachexia [94]. While the effects of $\mathrm{CD}^{+}$CTL and NK cell infiltration should be monitored, 
SMIs to GSK3 may offer one of the best and most cost-efficient therapies/co-therapies currently available to regulate both inclusion body formation and apoptosis in muscle tissue as well as the chronic inflammatory signaling in IBM. Some of the more promising inhibitors might be 9-ING-41 and Tideglusib, which have FDA orphan-drug status. Both demonstrate enhanced specificity and are currently in phase trials for diverse pathologies (see Table 4). As with all therapeutic interventions, one must weigh the patient benefit to the adverse events associated with the therapy. In most cases, the documented adverse events associated with GSK3 inhibition have ranged from mild to severe depending on the specific compound used. The mild side-effects, such as vertigo and diarrhea, to severe sideeffects, such as hypoglycemia, have been reported, with severe hypoglycemia being one of the main adverse events resulting in phase trial failure. While the phase trials utilizing 9-ING-41 are just getting well underway, a significant amount of data concerning the tolerability of Tideglusib is available. Most treatment-associated adverse events have been categorized as mild-to-moderate and have consisted of headache, diarrhea, cough, nausea, elevated liver transaminases (GGT and ALT) and creatine and fatigue. In a 2013 pilot study, and a phase II study in 2014 reported by del Ser et al. and Lovestone, et al., respectively, these adverse events were significant enough to result in a dropout rate of more than one-third of those enrolled in the trial [126-128]. So far, most studies utilizing 9-ING-41 and Tideglusib have been focused on Alzheimer's or cancer, although a number of studies utilizing Tideglusib have recently gotten underway to evaluate its use in amyotrophic lateral sclerosis (ALS) and myotonic dystrophy (https://clinicaltrials.gov/ct2/results? cond $=\&$ term $=$ Tideglusib\&cntry $=\&$ state $=\&$ city $=\&$ dist $=($ accessed on 17 November 2021 $)$ ). It will be necessary to determine the dose:benefit ratio in sIBM patients to determine if dosages sufficient for therapeutic response are above or below those reported previously for adverse events.

Table 4. A list of GSK3 inhibitors.

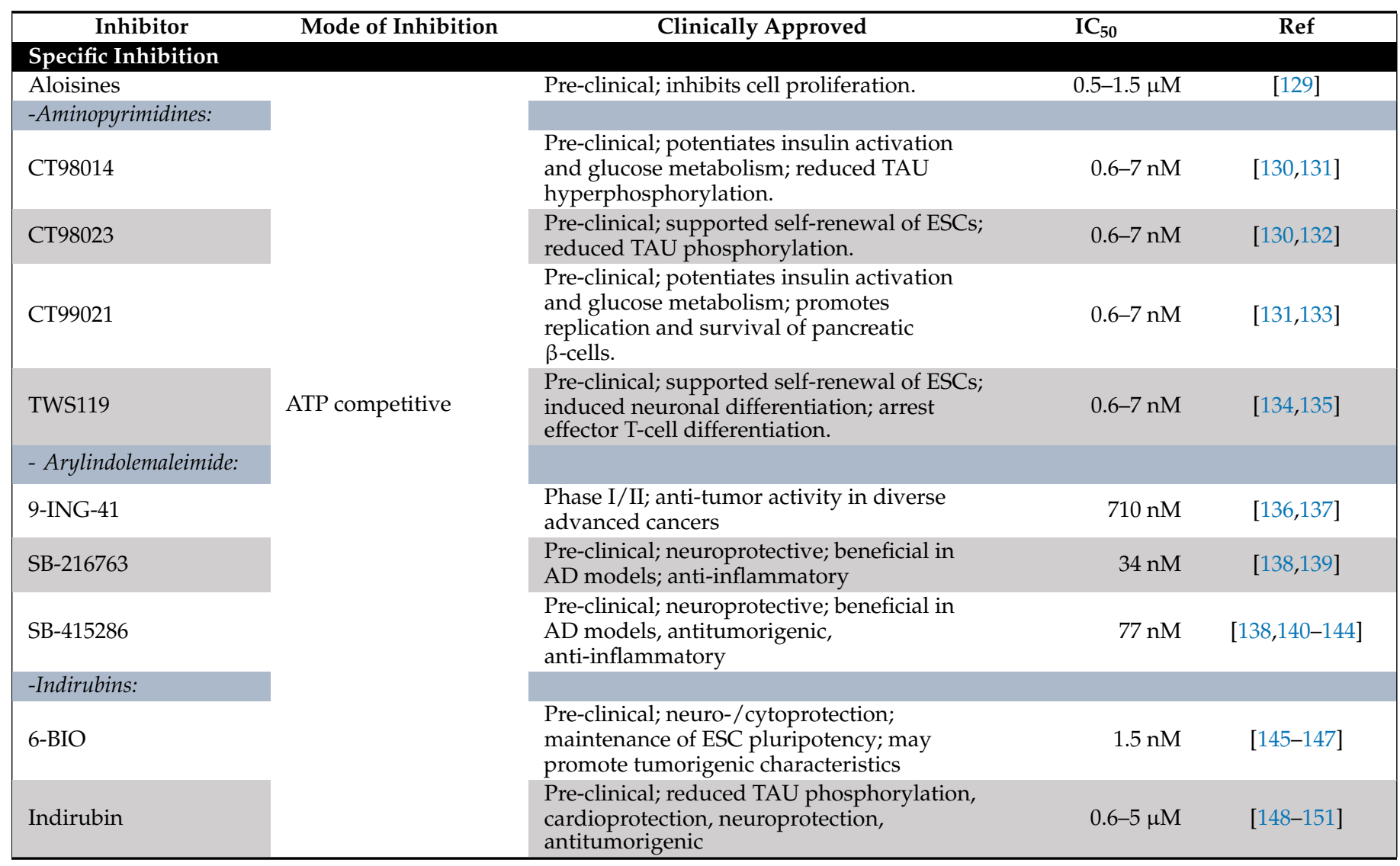


Table 4. Cont.

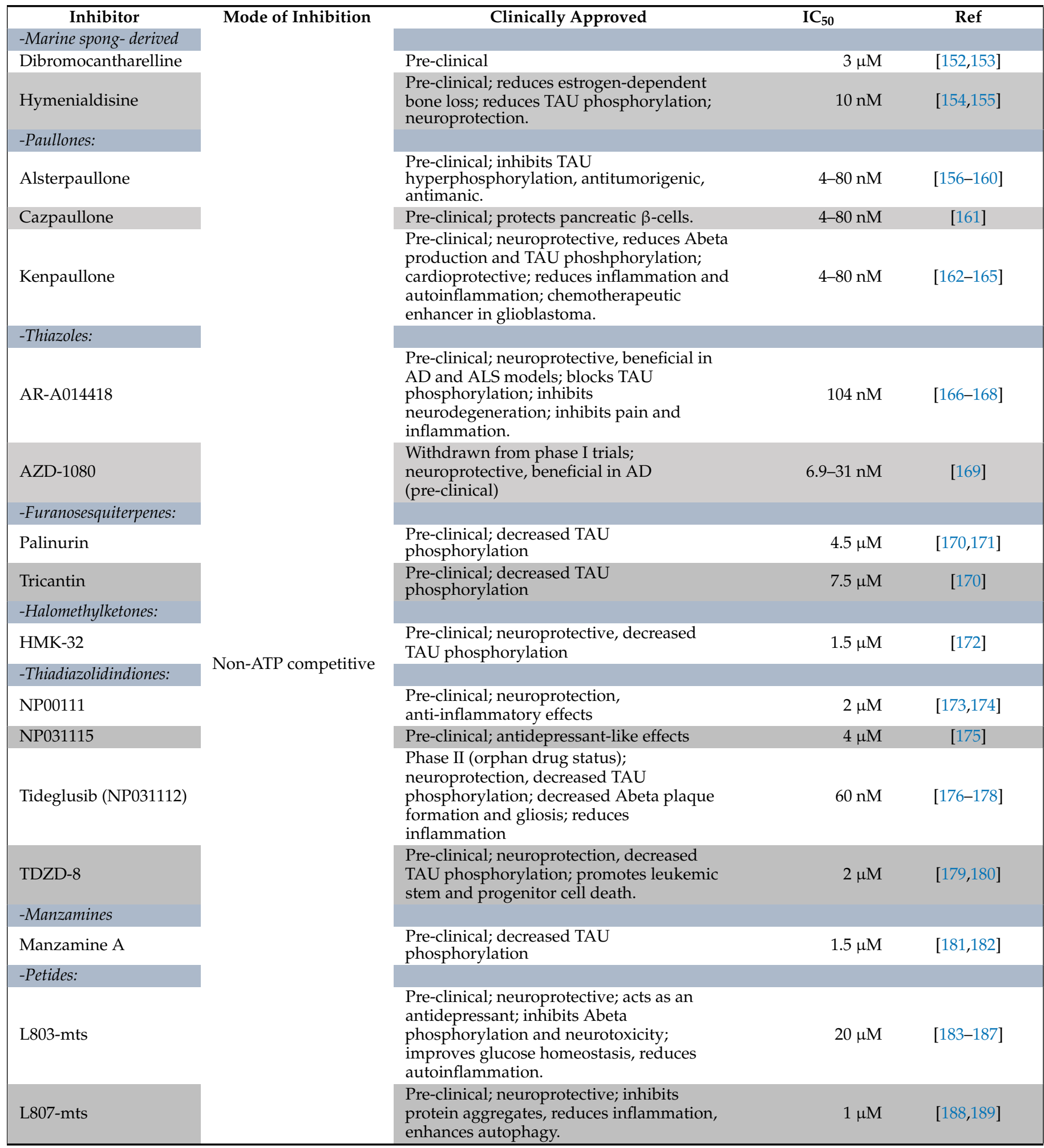


Table 4. Cont.

\begin{tabular}{|c|c|c|c|c|}
\hline Inhibitor & Mode of Inhibition & Clinically Approved & $\mathrm{IC}_{50}$ & Ref \\
\hline \multicolumn{5}{|l|}{$\begin{array}{l}\text { Non-specific } \\
\text { Inhibition }\end{array}$} \\
\hline Cromolyn & $\begin{array}{l}\text { Steric hindrance of the } \\
\text { binding pocket }\end{array}$ & $\begin{array}{l}\text { Non-steroidal, anti-inflammatory; Diabetes } \\
\text { mellitus }\end{array}$ & $2.0 \mu \mathrm{M}$ & [190] \\
\hline Curcumin & $\begin{array}{l}\text { Steric hindrance of the } \\
\text { binding pocket }\end{array}$ & $\begin{array}{l}\text { Dietary spice with a wide range of } \\
\text { pharmacological activities reported; } \\
\text { cardioprotective, neuroprotective, } \\
\text { anti-inflammatory. }\end{array}$ & $66.3 \mathrm{nM}$ & [191-197] \\
\hline Famotidine & $\begin{array}{l}\text { Steric hindrance of the } \\
\text { binding pocket }\end{array}$ & $\begin{array}{l}\text { H2-receptor antagonist used to treat gastric } \\
\text { reflux disease and peptic ulcer; has } \\
\text { neuroprotective effects }\end{array}$ & $1.44 \mu \mathrm{M}$ & {$[198,199]$} \\
\hline Lithium $\left(\mathrm{Li}^{++}\right)$ & Unknown & $\begin{array}{l}\text { Diabetes mellitus; bipolar disorder; } \\
\text { Alzheimer's and other neurodegenerative } \\
\text { diseases; neuroprotective effects, } \\
\text { anti-inflammatory effects. }\end{array}$ & $2 \mathrm{mM}$ & [200-204] \\
\hline Naproxen & $\begin{array}{l}\text { Steric hindrance of the } \\
\text { binding pocket }\end{array}$ & $\begin{array}{l}\text { Non-steroidal, anti-inflammatory; Diabetes } \\
\text { mellitus }\end{array}$ & $1.5 \mu \mathrm{M}$ & [190] \\
\hline Olanzapine & $\begin{array}{l}\text { Steric hindrance of the } \\
\text { binding pocket }\end{array}$ & $\begin{array}{l}\text { Antipsychotic used for schizophrenia, } \\
\text { bipolar disorder and anxiety; alters glucose } \\
\text { metabolism }\end{array}$ & $91.0 \mathrm{nM}$ & [205-207] \\
\hline $\operatorname{Zinc}\left(\mathrm{Zn}^{++}\right)$ & Unknown & $\begin{array}{l}\text { Antidepressant; alters glucose metabolism, } \\
\text { cardioprotective effects, neurotoxic effects }\end{array}$ & $15 \mu \mathrm{M}$ & [208-211] \\
\hline
\end{tabular}

Author Contributions: Conceptualization, M.P. and W.L.B.; Writing-Original Draft Preparation, W.L.B.; Writing-Review and Editing, M.P., A.B., V.C., I.F. and W.L.B.; Art and Graphical Design, M.P. All authors have read and agreed to the published version of the manuscript.

Funding: This research received no external funding.

Institutional Review Board Statement: Not applicable.

Informed Consent Statement: Not applicable.

Data Availability Statement: Not applicable.

Conflicts of Interest: The authors declare no conflict of interest.

\section{References}

1. Panginikkod, S.; Musa, R. Inclusion Body Myositis; StatPearls Publishing: Treasure Island, FL, USA, 2021.

2. Greenberg, S.A. Inclusion body myositis: Clinical features and pathogenesis. Nat. Rev. Rheumatol. 2019, 15, 257-272. [CrossRef]

3. Fratta, P.; Engel, W.K.; McFerrin, J.; Davies, K.J.; Lin, S.W.; Askanas, V. Proteasome inhibition and aggresome formation in sporadic inclusion-body myositis and in amyloid-beta precursor protein-overexpressing cultured human muscle fibers. Am. J. Pathol. 2005, 167, 517-526. [CrossRef]

4. Greenberg, S.A. Theories of the pathogenesis of inclusion body myositis. Curr. Rheumatol. Rep. 2010, 12, 221-228. [CrossRef] [PubMed]

5. Hedberg-Oldfors, C.; Lindgren, U.; Basu, S.; Visuttijai, K.; Lindberg, C.; Falkenberg, M.; Larsson Lekholm, E.; Oldfors, A. Mitochondrial DNA variants in inclusion body myositis characterized by deep sequencing. Brain Pathol. 2021, 31 , e12931. [CrossRef]

6. Dalakas, M.C.; Rakocevic, G.; Schmidt, J.; Salajegheh, M.; McElroy, B.; Harris-Love, M.O.; Shrader, J.A.; Levy, E.W.; Dambrosia, J.; Kampen, R.L.; et al. Effect of Alemtuzumab (CAMPATH 1-H) in patients with inclusion-body myositis. Brain A J. Neurol. 2009, 132, 1536-1544. [CrossRef] [PubMed]

7. Alemtuzumab to Treat Sporadic Inclusion Body Myositis. ClincalTrials.gov; US Library of Medicine. Available online: https: / / clinicaltrials.gov / ct2/show / NCT00079768 (accessed on 15 September 2021).

8. Leff, R.L.; Miller, F.W.; Hicks, J.; Fraser, D.D.; Plotz, P.H. The treatment of inclusion body myositis: A retrospective review and a randomized, prospective trial of immunosuppressive therapy. Medicine 1993, 72, 225-235. [CrossRef]

9. Soueidan, S.A.; Dalakas, M.C. Treatment of inclusion-body myositis with high-dose intravenous immunoglobulin. Neurology 1993, 43, 876-879. [CrossRef]

10. Amato, A.A.; Barohn, R.J.; Jackson, C.E.; Pappert, E.J.; Sahenk, Z.; Kissel, J.T. Inclusion body myositis: Treatment with intravenous immunoglobulin. Neurology 1994, 44, 1516-1518. [CrossRef]

11. Barohn, R.J.; Amato, A.A.; Sahenk, Z.; Kissel, J.T.; Mendell, J.R. Inclusion body myositis: Explanation for poor response to immunosuppressive therapy. Neurology 1995, 45, 1302-1304. [CrossRef] 
12. Lindberg, C.; Trysberg, E.; Tarkowski, A.; Oldfors, A. Anti-T-lymphocyte globulin treatment in inclusion body myositis: A randomized pilot study. Neurology 2003, 61, 260-262. [CrossRef]

13. Dalakas, M.C.; Sonies, B.; Dambrosia, J.; Sekul, E.; Cupler, E.; Sivakumar, K. Treatment of inclusion-body myositis with IVIg: A double-blind, placebo-controlled study. Neurology 1997, 48, 712-716. [CrossRef]

14. Walter, M.C.; Lochmuller, H.; Toepfer, M.; Schlotter, B.; Reilich, P.; Schroder, M.; Muller-Felber, W.; Pongratz, D. High-dose immunoglobulin therapy in sporadic inclusion body myositis: A double-blind, placebo-controlled study. J. Neurol. 2000, 247, 22-28. [CrossRef] [PubMed]

15. Dalakas, M.C.; Koffman, B.; Fujii, M.; Spector, S.; Sivakumar, K.; Cupler, E. A controlled study of intravenous immunoglobulin combined with prednisone in the treatment of IBM. Neurology 2001, 56, 323-327. [CrossRef]

16. Badrising, U.A.; Maat-Schieman, M.L.; Ferrari, M.D.; Zwinderman, A.H.; Wessels, J.A.; Breedveld, F.C.; van Doorn, P.A.; van Engelen, B.G.; Hoogendijk, J.E.; Howeler, C.J.; et al. Comparison of weakness progression in inclusion body myositis during treatment with methotrexate or placebo. Ann. Neurol. 2002, 51, 369-372. [CrossRef]

17. Kyriazopoulou, E.; Panagopoulos, P.; Metallidis, S.; Dalekos, G.N.; Poulakou, G.; Gatselis, N.; Karakike, E.; Saridaki, M.; Loli, G.; Stefos, A.; et al. An open label trial of anakinra to prevent respiratory failure in COVID-19. eLife 2021, 10, e66125. [CrossRef] [PubMed]

18. Ahmed, M.; Machado, P.M.; Miller, A.; Spicer, C.; Herbelin, L.; He, J.; Noel, J.; Wang, Y.; McVey, A.L.; Pasnoor, M.; et al. Targeting protein homeostasis in sporadic inclusion body myositis. Sci. Transl. Med. 2016, 8, 331ra341. [CrossRef] [PubMed]

19. Arimoclomol in Sporadic Inclusion Body Myositis-Open Label Extension Trial. ClincalTrials.gov; US Library of Medicine. Available online: https:/ / clinicaltrials.gov/ct2/show / NCT04049097 (accessed on 15 September 2021).

20. Arimoclomol in Sporadic Inclusion Body Myositis. ClincalTrials.gov; US Library of Medicine. Available online: https:// clinicaltrials.gov/ct2/show/study/NCT00769860 (accessed on 15 September 2021).

21. Study of Arimoclomol in Inclusion Body Myositis (IBM). ClincalTrials.gov; US Library of Congress. Available online: https: / / clinicaltrials.gov/ct2/show / NCT02753530 (accessed on 15 September 2021).

22. A Randomised, Double-Blind Placebo-Controlled Pilot Study Assessing the Safety and Tolerability of Arimoclomol in Adult with Sporadic Inclusion Body Myositis. EU Clinical Trials Register. European Medicines Agency. Available online: https: //www.clinicaltrialsregister.eu/ctr-search/trial/2008-008208-42/results (accessed on 15 September 2021).

23. Kosmidis, M.L.; Alexopoulos, H.; Tzioufas, A.G.; Dalakas, M.C. The effect of anakinra, an IL1 receptor antagonist, in patients with sporadic inclusion body myositis (sIBM): A small pilot study. J. Neurol. Sci. 2013, 334, 123-125. [CrossRef]

24. Anakinra in Myositis. ClincalTrials.gov; US Library of Medicine. Available online: https://clinicaltrials.gov/ct2/show/NCT011 65008 (accessed on 16 September 2021).

25. Oikawa, Y.; Izumi, R.; Koide, M.; Hagiwara, Y.; Kanzaki, M.; Suzuki, N.; Kikuchi, K.; Matsuhashi, T.; Akiyama, Y.; Ichijo, M.; et al. Mitochondrial dysfunction underlying sporadic inclusion body myositis is ameliorated by the mitochondrial homing drug MA-5. PLoS ONE 2020, 15, e0231064. [CrossRef] [PubMed]

26. A Phase 1 Study of ABC008 in Adult Patients With Inclusion Body Myositis (IBM). ClinicalTrials.gov; US National Library of Medicine. Available online: https:/ / clinicaltrials.gov/ct2/show / NCT04659031 (accessed on 16 September 2021).

27. An Open-Label, Non-Randomized Trial to Investigate the Efficacy and Safety of Early Versus Delayed Start of Arimoclomol in Patients with Sporadic Inclusion Body Myositis Who have Completed the IBM4809 Trial. EU Clinical Trials Register. European Medicines Agency. Available online: https:/ / www.clinicaltrialsregister.eu/ctr-search/trial/2019-000749-11/GB (accessed on 15 September 2021).

28. Phase $2 / 3$ Study of Arimoclomol in Inclusion Body Myositis (IBM). EU Clincal Trials Register. European Medicines Agency. Available online: https:/ / www.clinicaltrialsregister.eu/ctr-search/trial/2017-004903-33/GB (accessed on 15 September 2021).

29. A Randomised, Phase IIa Treatment Delayed-Start Trial of the Oral JAK 1/2 Inhibitor, Baricitinib, in the Treatment of Adult Idiopathic Inflammatory Myopathy. EU Clinical Trials Register. European Medicines Agency. Available online: https://www. clinicaltrialsregister.eu/ctr-search/trial/2019-003868-42/GB (accessed on 17 September 2021).

30. Can Local Intramuscular Botulinum Toxin Improve Dysphagia in Patients with Myopathic Dysphagia and Constriction of the Cricoid Muscle? EU Clinical Trials Register. European Medicines Agency. Available online: https:/ /www.clinicaltrialsregister. eu/ctr-search/trial/2014-002210-23/results (accessed on 17 September 2021).

31. Extension of the CBYM338B2203 Phase IIb/III Study to Evaluate the Long-Term Efficacy, Safety and Tolerability of Intravenous BYM338 in Patients with Sporadic Inclusion Body Myositis. EU Clincal Trials Register. European Medicines Agency. Available online: https:/ / www.clinicaltrialsregister.eu/ctr-search/trial/2015-001411-12/results (accessed on 17 September 2021).

32. An Extension Study of the Efficacy, Safety and Tolerability of BYM338 (Bimagrumab) in Patients With Sporadic Inclusion Body Myositis Who Previously Participated in the Core Study CBYM338B2203. ClinicalTrials.gov; US National Library of Medicine. Available online: https:/ / clinicaltrials.gov / ct2/show / NCT02573467 (accessed on 17 September 2021).

33. Amato, A.A.; Hanna, M.G.; Machado, P.M.; Badrising, U.A.; Chinoy, H.; Benveniste, O.; Karanam, A.K.; Wu, M.; Tanko, L.B.; Schubert-Tennigkeit, A.A.; et al. Efficacy and Safety of Bimagrumab in Sporadic Inclusion Body Myositis: Long-term Extension of RESILIENT. Neurology 2021, 96, e1595-e1607. [CrossRef]

34. Study of Long-term Safety, Efficacy Tolerability of BYM338 in Patients With Sporadic Inclusion Body Myositis (BYM338). ClinicalTrials.gov; US National Library of Medicine. Available online: https://clinicaltrials.gov/ct2/show/NCT02250443 (accessed on 17 September 2021). 
35. Sivakumar, K.; Cochrane, T.I.; Sloth, B.; Ashar, H.; Laurent, D.; Tanko, L.B.; Amato, A.A. Long-term safety and tolerability of bimagrumab (BYM338) in sporadic inclusion body myositis. Neurology 2020, 95, e1971-e1978. [CrossRef]

36. A Randomized, Double-Blind, Placebo-Controlled, Multicenter, Parallel Group, Dose-Finding, Pivotal, Phase 2b/3 Study to Evaluate the Efficacy, Safety, and Tolerability of Intravenous BYM338 at 52 Weeks on Physical Function, Muscle Strength, and Mobility and Additional Long-Term Safety Up to 2 Years in Patients with Sporadic Inclusion Body Myositis. EU Clinical Trials Register. European Medicines Agency. Available online: https://www.clinicaltrialsregister.eu/ctr-search/trial/2013-000705-23 / results (accessed on 17 September 2021).

37. Efficacy and Safety of Bimagrumab/BYM338 at 52 Weeks on Physical Function, Muscle Strength, Mobility in sIBM Patients (RESILIENT). ClinicalTrials.gov; US National Library of Medicine. Available online: https://clinicaltrials.gov/ct2/show/NCT0 1925209 (accessed on 17 September 2021).

38. Hanna, M.G.; Badrising, U.A.; Benveniste, O.; Lloyd, T.E.; Needham, M.; Chinoy, H.; Aoki, M.; Machado, P.M.; Liang, C.; Reardon, K.A.; et al. Safety and efficacy of intravenous bimagrumab in inclusion body myositis (RESILIENT): A randomised, double-blind, placebo-controlled phase 2b trial. Lancet. Neurol. 2019, 18, 834-844. [CrossRef]

39. Efficacy, Safety and Tolerability of BYM338 in Patients With Sporadic Inclusion Body Myositis. ClinicalTrials.gov; US Nationa Library of Medicine. Available online: https:/ / clinicaltrials.gov/ct2/show/NCT01423110 (accessed on 17 September 2021).

40. Amato, A.A.; Sivakumar, K.; Goyal, N.; David, W.S.; Salajegheh, M.; Praestgaard, J.; Lach-Trifilieff, E.; Trendelenburg, A.U.; Laurent, D.; Glass, D.J.; et al. Treatment of sporadic inclusion body myositis with bimagrumab. Neurology 2014, 83, 2239-2246. [CrossRef] [PubMed]

41. Double-blind, Randomized, Placebo-controlled Trial of Etanercept for 12 Months in Subjects With Inclusion Body Myositis. ClinicalTrials.gov; US National Library of Medicine. Available online: https://clinicaltrials.gov/ct2/show/NCT00802815 (accessed on 20 September 2021).

42. Barohn, R.J.; Herbelin, L.; Kissel, J.T.; King, W.; McVey, A.L.; Saperstein, D.S.; Mendell, J.R. Pilot trial of etanercept in the treatment of inclusion-body myositis. Neurology 2006, 66, S123-S124. [CrossRef]

43. Muscle Study, G. Randomized pilot trial of betaINF1a (Avonex) in patients with inclusion body myositis. Neurology 2001, 57, 1566-1570. [CrossRef]

44. Muscle Study, G. Randomized pilot trial of high-dose betaINF-1a in patients with inclusion body myositis. Neurology 2004, 63, 718-720. [CrossRef]

45. Intravenousimmunoglobulin (IVIg) for the Treatment of Inflammatory Myopathies. ClinicalTrials.gov; US National Library of Medicine. Available online: https:/ / clinicaltrials.gov/ct2/show/record/NCT00001261 (accessed on 20 September 2021).

46. Lithium in Inclusion Body Myositis (IBM) (Li-IBM). ClinicalTrials.gov; US National Library of Medicine. Available online: https: / / clinicaltrials.gov/ct2/show / NCT00917956 (accessed on 20 September 2021).

47. Natalizumab in Inclusion Body Myositis (IBM) (IBM-NAT). ClinicalTrials.gov; US National Library of Medicine. Available online: https: / / clinicaltrials.gov/ct2/show / NCT02483845 (accessed on 20 September 2021).

48. Rutkove, S.B.; Parker, R.A.; Nardin, R.A.; Connolly, C.E.; Felice, K.J.; Raynor, E.M. A pilot randomized trial of oxandrolone in inclusion body myositis. Neurology 2002, 58, 1081-1087. [CrossRef]

49. Safety and Tolerability of Phenylbutyrate in Inclusion Body Myositis. ClinicalTrials.gov; US National Library of Medicine. Available online: https:/ / clinicaltrials.gov/ct2/show / NCT04421677 (accessed on 21 September 2021).

50. Study of Pioglitazone in Sporadic Inclusion Body Myositis. ClinicalTrials.gov; US National Library of Medicine. Available online: https: / / clinicaltrials.gov/ct2/show / NCT03440034 (accessed on 21 September 2021).

51. Rapamycine vs Placebo for the Treatment of Inclusion Body Myositis (RAPAMI). ClinicalTrials.gov; US National Library of Medicine. Available online: https: / / clinicaltrials.gov/ct2/show / NCT02481453 (accessed on 21 September 2021).

52. Simvastatin treatment in inclusion body myositis (IBM). EU Clinical Trials Register. European Medicines Agency. Available online: https: / / www.clinicaltrialsregister.eu/ctr-search/trial/2007-004359-12/IT (accessed on 21 September 2021).

53. Simvastatin therapy in IBM. EU Clinical Trials Register. European Medicines Agency. Available online: https://www. clinicaltrialsregister.eu/ctr-search/trial/2006-005942-35/IT (accessed on 21 September 2021).

54. Phase III Trial of Sirolimus in IBM. ClinicalTrials.gov; US National Library of Medicine. Available online: https:/ / clinicaltrials. gov/ct2/show / NCT04789070 (accessed on 21 September 2021).

55. Inclusion Body Myositis Treatment With Celution Processed Adipose Derived Regenerative Cells. ClinicalTrials.gov; US National Library of Medicine. Available online: https:/ / clinicaltrials.gov/ct2/show/NCT04975841 (accessed on 14 September 2021).

56. Cell Therapy for IBM by Muscle Injection of ADSVF: A Phase I Trial (ADSVF-in-IBM). ClinicalTrials.gov; US National Library of Medicine. Available online: https:/ / clinicaltrials.gov/ct2/show / NCT05032131 (accessed on 14 September 2021).

57. Follistatin Gene Transfer to Patients With Becker Muscular Dystrophy and Sporadic Inclusion Body Myositis. ClinicalTrials.gov; US National Library of Medicine. Available online: https:/ / clinicaltrials.gov/ct2/show/NCT01519349 (accessed on 14 September 2021).

58. Mendell, J.R.; Sahenk, Z.; Al-Zaidy, S.; Rodino-Klapac, L.R.; Lowes, L.P.; Alfano, L.N.; Berry, K.; Miller, N.; Yalvac, M.; Dvorchik, I.; et al. Follistatin Gene Therapy for Sporadic Inclusion Body Myositis Improves Functional Outcomes. Mol. Ther. J. Am. Soc. Gene Ther. 2017, 25, 870-879. [CrossRef]

59. Nagini, S.; Sophia, J.; Mishra, R. Glycogen synthase kinases: Moonlighting proteins with theranostic potential in cancer. Semin. Cancer Biol. 2019, 56, 25-36. [CrossRef] 
60. Mancinelli, R.; Carpino, G.; Petrungaro, S.; Mammola, C.L.; Tomaipitinca, L.; Filippini, A.; Facchiano, A.; Ziparo, E.; Giampietri, C. Multifaceted Roles of GSK-3 in Cancer and Autophagy-Related Diseases. Oxidative Med. Cell. Longev. 2017, $2017,4629495$. [CrossRef] [PubMed]

61. Uhlen, M.; Fagerberg, L.; Hallstrom, B.M.; Lindskog, C.; Oksvold, P.; Mardinoglu, A.; Sivertsson, A.; Kampf, C.; Sjostedt, E.; Asplund, A.; et al. Proteomics. Tissue-based map of the human proteome. Science 2015, 347, 1260419. [CrossRef]

62. Hornbeck, P.V.; Zhang, B.; Murray, B.; Kornhauser, J.M.; Latham, V.; Skrzypek, E. PhosphoSitePlus, 2014: Mutations, PTMs and recalibrations. Nucleic Acids Res. 2015, 43, D512-D520. [CrossRef]

63. Cole, A.; Frame, S.; Cohen, P. Further evidence that the tyrosine phosphorylation of glycogen synthase kinase-3 (GSK3) in mammalian cells is an autophosphorylation event. Biochem. J. 2004, 377, 249-255. [CrossRef]

64. Takahashi-Yanaga, F.; Shiraishi, F.; Hirata, M.; Miwa, Y.; Morimoto, S.; Sasaguri, T. Glycogen synthase kinase-3beta is tyrosinephosphorylated by MEK1 in human skin fibroblasts. Biochem. Biophys. Res. Commun. 2004, 316, 411-415. [CrossRef] [PubMed]

65. McCubrey, J.A.; Steelman, L.S.; Bertrand, F.E.; Davis, N.M.; Sokolosky, M.; Abrams, S.L.; Montalto, G.; D'Assoro, A.B.; Libra, M.; Nicoletti, F.; et al. GSK-3 as potential target for therapeutic intervention in cancer. Oncotarget 2014, 5, 2881-2911. [CrossRef] [PubMed]

66. Sayas, C.L.; Ariaens, A.; Ponsioen, B.; Moolenaar, W.H. GSK-3 is activated by the tyrosine kinase Pyk2 during LPA1-mediated neurite retraction. Mol. Biol. Cell 2006, 17, 1834-1844. [CrossRef]

67. Forde, J.E.; Dale, T.C. Glycogen synthase kinase 3: A key regulator of cellular fate. Cell. Mol. Life Sci. CMLS 2007, 64, 1930-1944. [CrossRef]

68. Park, S.A.; Ahn, S.I.; Gallo, J.M. Tau mis-splicing in the pathogenesis of neurodegenerative disorders. BMB Rep. 2016, 49, 405-413. [CrossRef]

69. Balaji, V.; Kaniyappan, S.; Mandelkow, E.; Wang, Y.; Mandelkow, E.M. Pathological missorting of endogenous MAPT/Tau in neurons caused by failure of protein degradation systems. Autophagy 2018, 14, 2139-2154. [CrossRef]

70. Bose, A.; Mouton-Liger, F.; Paquet, C.; Mazot, P.; Vigny, M.; Gray, F.; Hugon, J. Modulation of tau phosphorylation by the kinase PKR: Implications in Alzheimer's disease. Brain Pathol. 2011, 21, 189-200. [CrossRef] [PubMed]

71. Hugon, J.; Mouton-Liger, F.; Dumurgier, J.; Paquet, C. PKR involvement in Alzheimer's disease. Alzheimer Res. Ther. 2017, 9, 83. [CrossRef]

72. Llorens-Martin, M.; Jurado, J.; Hernandez, F.; Avila, J. GSK-3beta, a pivotal kinase in Alzheimer disease. Front. Mol. Neurosci. 2014, 7, 46. [CrossRef]

73. Singh, T.J.; Grundke-Iqbal, I.; Wu, W.Q.; Chauhan, V.; Novak, M.; Kontzekova, E.; Iqbal, K. Protein kinase C and calcium/calmodulin-dependent protein kinase II phosphorylate three-repeat and four-repeat tau isoforms at different rates. Mol. Cell. Biochem. 1997, 168, 141-148. [CrossRef]

74. Wang, J.Z.; Wu, Q.; Smith, A.; Grundke-Iqbal, I.; Iqbal, K. Tau is phosphorylated by GSK-3 at several sites found in Alzheimer disease and its biological activity markedly inhibited only after it is prephosphorylated by A-kinase. FEBS Lett. 1998, 436, 28-34. [CrossRef]

75. Mailliot, C.; Podevin-Dimster, V.; Rosenthal, R.E.; Sergeant, N.; Delacourte, A.; Fiskum, G.; Buee, L. Rapid tau protein dephosphorylation and differential rephosphorylation during cardiac arrest-induced cerebral ischemia and reperfusion. J. Cereb. Blood Flow Metab. Off. J. Int. Soc. Cereb. Blood Flow Metab. 2000, 20, 543-549. [CrossRef] [PubMed]

76. Illenberger, S.; Zheng-Fischhofer, Q.; Preuss, U.; Stamer, K.; Baumann, K.; Trinczek, B.; Biernat, J.; Godemann, R.; Mandelkow, E.M.; Mandelkow, E. The endogenous and cell cycle-dependent phosphorylation of tau protein in living cells: Implications for Alzheimer's disease. Mol. Biol. Cell 1998, 9, 1495-1512. [CrossRef] [PubMed]

77. Schneider, A.; Biernat, J.; von Bergen, M.; Mandelkow, E.; Mandelkow, E.M. Phosphorylation that detaches tau protein from microtubules (Ser262, Ser214) also protects it against aggregation into Alzheimer paired helical filaments. Biochemistry 1999, 38, 3549-3558. [CrossRef]

78. Liu, F.; Li, B.; Tung, E.J.; Grundke-Iqbal, I.; Iqbal, K.; Gong, C.X. Site-specific effects of tau phosphorylation on its microtubule assembly activity and self-aggregation. Eur. J. Neurosci. 2007, 26, 3429-3436. [CrossRef] [PubMed]

79. Liu, F.; Liang, Z.; Shi, J.; Yin, D.; El-Akkad, E.; Grundke-Iqbal, I.; Iqbal, K.; Gong, C.X. PKA modulates GSK-3beta- and cdk5-catalyzed phosphorylation of tau in site- and kinase-specific manners. FEBS Lett. 2006, 580, 6269-6274. [CrossRef] [PubMed]

80. Liu, F.; Iqbal, K.; Grundke-Iqbal, I.; Gong, C.X. Involvement of aberrant glycosylation in phosphorylation of tau by cdk5 and GSK-3beta. FEBS Lett. 2002, 530, 209-214. [CrossRef]

81. Leroy, A.; Landrieu, I.; Huvent, I.; Legrand, D.; Codeville, B.; Wieruszeski, J.M.; Lippens, G. Spectroscopic studies of GSK3\{beta\} phosphorylation of the neuronal tau protein and its interaction with the N-terminal domain of apolipoprotein E. J. Biol. Chem. 2010, 285, 33435-33444. [CrossRef]

82. Qian, W.; Shi, J.; Yin, X.; Iqbal, K.; Grundke-Iqbal, I.; Gong, C.X.; Liu, F. PP2A regulates tau phosphorylation directly and also indirectly via activating GSK-3beta. J. Alzheimer Dis. JAD 2010, 19, 1221-1229. [CrossRef]

83. Sengupta, A.; Novak, M.; Grundke-Iqbal, I.; Iqbal, K. Regulation of phosphorylation of tau by cyclin-dependent kinase 5 and glycogen synthase kinase-3 at substrate level. FEBS Lett. 2006, 580, 5925-5933. [CrossRef]

84. Sengupta, A.; Kabat, J.; Novak, M.; Wu, Q.; Grundke-Iqbal, I.; Iqbal, K. Phosphorylation of tau at both Thr 231 and Ser 262 is required for maximal inhibition of its binding to microtubules. Arch. Biochem. Biophys. 1998, 357, 299-309. [CrossRef] [PubMed] 
85. Moszczynski, A.J.; Gohar, M.; Volkening, K.; Leystra-Lantz, C.; Strong, W.; Strong, M.J. Thr175-phosphorylated tau induces pathologic fibril formation via GSK3beta-mediated phosphorylation of Thr231 in vitro. Neurobiol. Aging 2015, 36, 1590-1599. [CrossRef] [PubMed]

86. Tatebayashi, Y.; Planel, E.; Chui, D.H.; Sato, S.; Miyasaka, T.; Sahara, N.; Murayama, M.; Kikuchi, N.; Yoshioka, K.; Rivka, R.; et al. c-jun N-terminal kinase hyperphosphorylates R406W tau at the PHF-1 site during mitosis. FASEB J. Off. Publ. Fed. Am. Soc. Exp. Biol. 2006, 20, 762-764. [CrossRef] [PubMed]

87. Azorsa, D.O.; Robeson, R.H.; Frost, D.; Meec Hoovet, B.; Brautigam, G.R.; Dickey, C.; Beaudry, C.; Basu, G.D.; Holz, D.R.; Hernandez, J.A.; et al. High-content siRNA screening of the kinome identifies kinases involved in Alzheimer's disease-related tau hyperphosphorylation. BMC Genom. 2010, 11, 25. [CrossRef]

88. Ho, Y.S.; Yang, X.; Lau, J.C.; Hung, C.H.; Wuwongse, S.; Zhang, Q.; Wang, J.; Baum, L.; So, K.F.; Chang, R.C. Endoplasmic reticulum stress induces tau pathology and forms a vicious cycle: Implication in Alzheimer's disease pathogenesis. J. Alzheimer Dis. JAD 2012, 28, 839-854. [CrossRef]

89. Nijholt, D.A.; van Haastert, E.S.; Rozemuller, A.J.; Scheper, W.; Hoozemans, J.J. The unfolded protein response is associated with early tau pathology in the hippocampus of tauopathies. J. Pathol. 2012, 226, 693-702. [CrossRef]

90. Abisambra, J.F.; Jinwal, U.K.; Blair, L.J.; O'Leary, J.C., III; Li, Q.; Brady, S.; Wang, L.; Guidi, C.E.; Zhang, B.; Nordhues, B.A.; et al. Tau accumulation activates the unfolded protein response by impairing endoplasmic reticulum-associated degradation. J. Neurosci. Off. J. Soc. Neurosci. 2013, 33, 9498-9507. [CrossRef]

91. Lu, B.; Nakamura, T.; Inouye, K.; Li, J.; Tang, Y.; Lundback, P.; Valdes-Ferrer, S.I.; Olofsson, P.S.; Kalb, T.; Roth, J.; et al. Novel role of PKR in inflammasome activation and HMGB1 release. Nature 2012, 488, 670-674. [CrossRef]

92. Van Zeller, M.; Dias, D.M.; Sebastiao, A.M.; Valente, C.A. NLRP3 Inflammasome: A Starring Role in Amyloid-beta- and Tau-Driven Pathological Events in Alzheimer's Disease. J. Alzheimer Dis. JAD 2021, 83, 939-961. [CrossRef] [PubMed]

93. Reimer, L.; Betzer, C.; Kofoed, R.H.; Volbracht, C.; Fog, K.; Kurhade, C.; Nilsson, E.; Overby, A.K.; Jensen, P.H. PKR kinase directly regulates tau expression and Alzheimer's disease-related tau phosphorylation. Brain Pathol. 2021, 31, 103-119. [CrossRef]

94. Piazzi, M.; Bavelloni, A.; Faenza, I.; Blalock, W. Glycogen synthase kinase (GSK)-3 and the double-strand RNA-dependent kinase, PKR: When two kinases for the common good turn bad. Biochim. Et Biophys. Acta Mol. Cell Res. 2020, 1867, 118769. [CrossRef]

95. Takashima, A. GSK-3 is essential in the pathogenesis of Alzheimer's disease. J. Alzheimer's Dis. JAD 2006, 9, 309-317. [CrossRef] [PubMed]

96. Sayas, C.L.; Avila, J. GSK-3 and Tau: A Key Duet in Alzheimer's Disease. Cells 2021, 10, 721. [CrossRef] [PubMed]

97. Chahin, N.; Engel, A.G. Correlation of muscle biopsy, clinical course, and outcome in PM and sporadic IBM. Neurology 2008, 70, 418-424. [CrossRef]

98. Temiz, P.; Weihl, C.C.; Pestronk, A. Inflammatory myopathies with mitochondrial pathology and protein aggregates. J. Neurol. Sci. 2009, 278, 25-29. [CrossRef]

99. Kitazawa, M.; Green, K.N.; Caccamo, A.; LaFerla, F.M. Genetically augmenting Abeta42 levels in skeletal muscle exacerbates inclusion body myositis-like pathology and motor deficits in transgenic mice. Am. J. Pathol. 2006, 168, 1986-1997. [CrossRef]

100. Kitazawa, M.; Trinh, D.N.; LaFerla, F.M. Inflammation induces tau pathology in inclusion body myositis model via glycogen synthase kinase-3beta. Ann. Neurol. 2008, 64, 15-24. [CrossRef]

101. Nicot, A.S.; Lo Verso, F.; Ratti, F.; Pilot-Storck, F.; Streichenberger, N.; Sandri, M.; Schaeffer, L.; Goillot, E. Phosphorylation of NBR1 by GSK3 modulates protein aggregation. Autophagy 2014, 10, 1036-1053. [CrossRef]

102. Chou, S.M. Myxovirus-like structures in a case of human chronic polymyositis. Science 1967, 158, 1453-1455. [CrossRef]

103. Ciaccio, M.; Lo Sasso, B.; Scazzone, C.; Gambino, C.M.; Ciaccio, A.M.; Bivona, G.; Piccoli, T.; Giglio, R.V.; Agnello, L. COVID-19 and Alzheimer's Disease. Brain Sci. 2021, 11, 305. [CrossRef] [PubMed]

104. Zhou, Y.; Xu, J.; Hou, Y.; Leverenz, J.B.; Kallianpur, A.; Mehra, R.; Liu, Y.; Yu, H.; Pieper, A.A.; Jehi, L.; et al. Network medicine links SARS-CoV-2/COVID-19 infection to brain microvascular injury and neuroinflammation in dementia-like cognitive impairment. Alzheimer Res. Ther. 2021, 13, 110. [CrossRef]

105. Ioannidou, A.; Goulielmaki, E.; Garinis, G.A. DNA Damage: From Chronic Inflammation to Age-Related Deterioration. Front. Genet. 2016, 7, 187. [CrossRef]

106. Cheng, X.; Byrne, M.; Brown, K.D.; Konopleva, M.Y.; Kornblau, S.M.; Bennett, R.L.; May, W.S. PKR inhibits the DNA damage response, and is associated with poor survival in AML and accelerated leukemia in NHD13 mice. Blood 2015, 126, 1585-1594. [CrossRef] [PubMed]

107. Shen, H.H.; Yang, Y.X.; Meng, X.; Luo, X.Y.; Li, X.M.; Shuai, Z.W.; Ye, D.Q.; Pan, H.F. NLRP3: A promising therapeutic target for autoimmune diseases. Autoimmun. Rev. 2018, 17, 694-702. [CrossRef]

108. Wang, H.; Brown, J.; Martin, M. Glycogen synthase kinase 3: A point of convergence for the host inflammatory response. Cytokine 2011, 53, 130-140. [CrossRef]

109. Beurel, E.; Michalek, S.M.; Jope, R.S. Innate and adaptive immune responses regulated by glycogen synthase kinase-3 (GSK3). Trends Immunol. 2010, 31, 24-31. [CrossRef] [PubMed]

110. Ko, R.; Park, J.H.; Ha, H.; Choi, Y.; Lee, S.Y. Glycogen synthase kinase 3beta ubiquitination by TRAF6 regulates TLR3-mediated pro-inflammatory cytokine production. Nat. Commun. 2015, 6, 6765. [CrossRef] 
111. Zhou, H.; Wang, H.; Ni, M.; Yue, S.; Xia, Y.; Busuttil, R.W.; Kupiec-Weglinski, J.W.; Lu, L.; Wang, X.; Zhai, Y. Glycogen synthase kinase 3beta promotes liver innate immune activation by restraining AMP-activated protein kinase activation. J. Hepatol. 2018, 69, 99-109. [CrossRef]

112. Prantner, D.; Perkins, D.J.; Vogel, S.N. AMP-activated Kinase (AMPK) Promotes Innate Immunity and Antiviral Defense through Modulation of Stimulator of Interferon Genes (STING) Signaling. J. Biol. Chem. 2017, 292, 292-304. [CrossRef] [PubMed]

113. Marineau, A.; Khan, K.A.; Servant, M.J. Roles of GSK-3 and beta-Catenin in Antiviral Innate Immune Sensing of Nucleic Acids. Cells 2020, 9, 897. [CrossRef]

114. Du, X.; He, W.; He, H.; Wang, H. Beta-catenin inhibits bovine parainfluenza virus type 3 replication via innate immunity pathway. BMC Vet. Res. 2020, 16, 72. [CrossRef]

115. Qin, Y.; Liu, Q.; Tian, S.; Xie, W.; Cui, J.; Wang, R.F. TRIM9 short isoform preferentially promotes DNA and RNA virus-induced production of type I interferon by recruiting GSK3beta to TBK1. Cell Res. 2016, 26, 613-628. [CrossRef]

116. Khan, K.A.; Do, F.; Marineau, A.; Doyon, P.; Clement, J.F.; Woodgett, J.R.; Doble, B.W.; Servant, M.J. Fine-Tuning of the RIG-I-Like Receptor/Interferon Regulatory Factor 3-Dependent Antiviral Innate Immune Response by the Glycogen Synthase Kinase 3/beta-Catenin Pathway. Mol. Cell. Biol. 2015, 35, 3029-3043. [CrossRef]

117. Wang, J.T.; Chang, L.S.; Chen, C.J.; Doong, S.L.; Chang, C.W.; Chen, M.R. Glycogen synthase kinase 3 negatively regulates IFN regulatory factor 3 transactivation through phosphorylation at its linker region. Innate Immun. 2014, 20, 78-87. [CrossRef] [PubMed]

118. Stamos, J.L.; Weis, W.I. The beta-catenin destruction complex. Cold Spring Harb. Perspect. Biol. 2013, 5, a007898. [CrossRef] [PubMed]

119. Li, M.; Chen, H.; Chen, L.; Chen, Y.; Liu, X.; Mo, D. miR-709 modulates LPS-induced inflammatory response through targeting GSK-3beta. Int. Immunopharmacol. 2016, 36, 333-338. [CrossRef]

120. Londino, J.D.; Gulick, D.L.; Lear, T.B.; Suber, T.L.; Weathington, N.M.; Masa, L.S.; Chen, B.B.; Mallampalli, R.K. Post-translational modification of the interferon-gamma receptor alters its stability and signaling. Biochem. J. 2017, 474, 3543-3557. [CrossRef]

121. Beurel, E.; Jope, R.S. Glycogen synthase kinase-3 promotes the synergistic action of interferon-gamma on lipopolysaccharideinduced IL-6 production in RAW264.7 cells. Cell. Signal. 2009, 21, 978-985. [CrossRef]

122. Hu, X.; Paik, P.K.; Chen, J.; Yarilina, A.; Kockeritz, L.; Lu, T.T.; Woodgett, J.R.; Ivashkiv, L.B. IFN-gamma suppresses IL-10 production and synergizes with TLR2 by regulating GSK3 and CREB/AP-1 proteins. Immunity 2006, 24, 563-574. [CrossRef]

123. Lin, C.F.; Tsai, C.C.; Huang, W.C.; Wang, C.Y.; Tseng, H.C.; Wang, Y.; Kai, J.I.; Wang, S.W.; Cheng, Y.L. IFN-gamma synergizes with LPS to induce nitric oxide biosynthesis through glycogen synthase kinase-3-inhibited IL-10. J. Cell. Biochem. 2008, 105, 746-755. [CrossRef]

124. Blanco-Melo, D.; Nilsson-Payant, B.E.; Liu, W.C.; Uhl, S.; Hoagland, D.; Moller, R.; Jordan, T.X.; Oishi, K.; Panis, M.; Sachs, D.; et al. Imbalanced Host Response to SARS-CoV-2 Drives Development of COVID-19. Cell 2020, 181, 1036-1045. [CrossRef]

125. Rudd, C.E. GSK-3 Inhibition as a Therapeutic Approach Against SARs CoV2: Dual Benefit of Inhibiting Viral Replication While Potentiating the Immune Response. Front. Immunol. 2020, 11, 1638. [CrossRef]

126. del Ser, T.; Steinwachs, K.C.; Gertz, H.J.; Andres, M.V.; Gomez-Carrillo, B.; Medina, M.; Vericat, J.A.; Redondo, P.; Fleet, D.; Leon, T. Treatment of Alzheimer's disease with the GSK-3 inhibitor tideglusib: A pilot study. J. Alzheimer Dis. JAD 2013, 33, 205-215. [CrossRef] [PubMed]

127. Lovestone, S.; Boada, M.; Dubois, B.; Hull, M.; Rinne, J.O.; Huppertz, H.J.; Calero, M.; Andres, M.V.; Gomez-Carrillo, B.; Leon, T.; et al. A phase II trial of tideglusib in Alzheimer's disease. J. Alzheimer Dis. JAD 2015, 45, 75-88. [CrossRef]

128. Hostiuc, S.; Perlea, P.; Marinescu, M.; Dogaroiu, C.; Drima, E. GSK-3 Inhibitors and Tooth Repair: An Ethical Analysis. Front. Pharmacol. 2018, 9, 1495. [CrossRef] [PubMed]

129. Mettey, Y.; Gompel, M.; Thomas, V.; Garnier, M.; Leost, M.; Ceballos-Picot, I.; Noble, M.; Endicott, J.; Vierfond, J.M.; Meijer, L. Aloisines, a new family of CDK/GSK-3 inhibitors. SAR study, crystal structure in complex with CDK2, enzyme selectivity, and cellular effects. J. Med. Chem. 2003, 46, 222-236. [CrossRef]

130. Selenica, M.L.; Jensen, H.S.; Larsen, A.K.; Pedersen, M.L.; Helboe, L.; Leist, M.; Lotharius, J. Efficacy of small-molecule glycogen synthase kinase-3 inhibitors in the postnatal rat model of tau hyperphosphorylation. Br. J. Pharmacol. 2007, 152, 959-979. [CrossRef]

131. Ring, D.B.; Johnson, K.W.; Henriksen, E.J.; Nuss, J.M.; Goff, D.; Kinnick, T.R.; Ma, S.T.; Reeder, J.W.; Samuels, I.; Slabiak, T.; et al. Selective glycogen synthase kinase 3 inhibitors potentiate insulin activation of glucose transport and utilization in vitro and in vivo. Diabetes 2003, 52, 588-595. [CrossRef] [PubMed]

132. Li, W.; Sun, W.; Zhang, Y.; Wei, W.; Ambasudhan, R.; Xia, P.; Talantova, M.; Lin, T.; Kim, J.; Wang, X.; et al. Rapid induction and long-term self-renewal of primitive neural precursors from human embryonic stem cells by small molecule inhibitors. Proc. Natl. Acad. Sci. USA 2011, 108, 8299-8304. [CrossRef] [PubMed]

133. Mussmann, R.; Geese, M.; Harder, F.; Kegel, S.; Andag, U.; Lomow, A.; Burk, U.; Onichtchouk, D.; Dohrmann, C.; Austen, M. Inhibition of GSK3 promotes replication and survival of pancreatic beta cells. J. Biol. Chem. 2007, 282, 12030-12037. [CrossRef] [PubMed]

134. Ding, S.; Wu, T.Y.; Brinker, A.; Peters, E.C.; Hur, W.; Gray, N.S.; Schultz, P.G. Synthetic small molecules that control stem cell fate. Proc. Natl. Acad. Sci. USA 2003, 100, 7632-7637. [CrossRef] 
135. Muralidharan, S.; Hanley, P.J.; Liu, E.; Chakraborty, R.; Bollard, C.; Shpall, E.; Rooney, C.; Savoldo, B.; Rodgers, J.; Dotti, G. Activation of Wnt signaling arrests effector differentiation in human peripheral and cord blood-derived T lymphocytes. J. Immunol. 2011, 187, 5221-5232. [CrossRef]

136. Ugolkov, A.V.; Bondarenko, G.I.; Dubrovskyi, O.; Berbegall, A.P.; Navarro, S.; Noguera, R.; O'Halloran, T.V.; Hendrix, M.J.; Giles, F.J.; Mazar, A.P. 9-ING-41, a small-molecule glycogen synthase kinase-3 inhibitor, is active in neuroblastoma. Anti-Cancer Drugs 2018, 29, 717-724. [CrossRef]

137. Wu, X.; Stenson, M.; Abeykoon, J.; Nowakowski, K.; Zhang, L.; Lawson, J.; Wellik, L.; Li, Y.; Krull, J.; Wenzl, K.; et al. Targeting glycogen synthase kinase 3 for therapeutic benefit in lymphoma. Blood 2019, 134, 363-373. [CrossRef]

138. Cross, D.A.; Culbert, A.A.; Chalmers, K.A.; Facci, L.; Skaper, S.D.; Reith, A.D. Selective small-molecule inhibitors of glycogen synthase kinase-3 activity protect primary neurones from death. J. Neurochem. 2001, 77, 94-102. [CrossRef]

139. Gurrieri, C.; Piazza, F.; Gnoato, M.; Montini, B.; Biasutto, L.; Gattazzo, C.; Brunetta, E.; Cabrelle, A.; Cinetto, F.; Niero, R.; et al. 3-(2,4-dichlorophenyl)-4-(1-methyl-1H-indol-3-yl)-1H-pyrrole-2,5-dione (SB216763), a glycogen synthase kinase-3 inhibitor, displays therapeutic properties in a mouse model of pulmonary inflammation and fibrosis. J. Pharmacol. Exp. Ther. 2010, 332, 785-794. [CrossRef] [PubMed]

140. Dickey, A.; Schleicher, S.; Leahy, K.; Hu, R.; Hallahan, D.; Thotala, D.K. GSK-3beta inhibition promotes cell death, apoptosis, and in vivo tumor growth delay in neuroblastoma Neuro-2A cell line. J. Neuro-Oncol. 2011, 104, 145-153. [CrossRef]

141. Piazza, F.; Manni, S.; Tubi, L.Q.; Montini, B.; Pavan, L.; Colpo, A.; Gnoato, M.; Cabrelle, A.; Adami, F.; Zambello, R.; et al. Glycogen Synthase Kinase-3 regulates multiple myeloma cell growth and bortezomib-induced cell death. BMC Cancer 2010, 10, 526. [CrossRef]

142. Pizarro, J.G.; Yeste-Velasco, M.; Rimbau, V.; Casadesus, G.; Smith, M.A.; Pallas, M.; Folch, J.; Camins, A. Neuroprotective effects of SB-415286 on hydrogen peroxide-induced cell death in $\mathrm{B} 65$ rat neuroblastoma cells and neurons. Int. J. Dev. Neurosci. Off. J. Int. Soc. Dev. Neurosci. 2008, 26, 269-276. [CrossRef]

143. Whittle, B.J.; Varga, C.; Posa, A.; Molnar, A.; Collin, M.; Thiemermann, C. Reduction of experimental colitis in the rat by inhibitors of glycogen synthase kinase-3beta. Br. J. Pharmacol. 2006, 147, 575-582. [CrossRef] [PubMed]

144. Coghlan, M.P.; Culbert, A.A.; Cross, D.A.; Corcoran, S.L.; Yates, J.W.; Pearce, N.J.; Rausch, O.L.; Murphy, G.J.; Carter, P.S.; Roxbee Cox, L.; et al. Selective small molecule inhibitors of glycogen synthase kinase-3 modulate glycogen metabolism and gene transcription. Chem. Biol. 2000, 7, 793-803. [CrossRef]

145. Sato, N.; Meijer, L.; Skaltsounis, L.; Greengard, P.; Brivanlou, A.H. Maintenance of pluripotency in human and mouse embryonic stem cells through activation of Wnt signaling by a pharmacological GSK-3-specific inhibitor. Nat. Med. 2004, 10, 55-63. [CrossRef] [PubMed]

146. Sklirou, A.D.; Gaboriaud-Kolar, N.; Papassideri, I.; Skaltsounis, A.L.; Trougakos, I.P. 6-bromo-indirubin-3'-oxime (6BIO), a Glycogen synthase kinase-3beta inhibitor, activates cytoprotective cellular modules and suppresses cellular senescence-mediated biomolecular damage in human fibroblasts. Sci. Rep. 2017, 7, 11713. [CrossRef]

147. Liu, K.; Li, J.; Wu, X.; Chen, M.; Luo, F.; Li, J. GSK-3beta inhibitor 6-bromo-indirubin-3'-oxime promotes both adhesive activity and drug resistance in colorectal cancer cells. Int. J. Oncol. 2017, 51, 1821-1830. [CrossRef]

148. Leclerc, S.; Garnier, M.; Hoessel, R.; Marko, D.; Bibb, J.A.; Snyder, G.L.; Greengard, P.; Biernat, J.; Wu, Y.Z.; Mandelkow, E.M.; et al. Indirubins inhibit glycogen synthase kinase-3 beta and CDK5/p25, two protein kinases involved in abnormal tau phosphorylation in Alzheimer's disease. A property common to most cyclin-dependent kinase inhibitors? J. Biol. Chem. 2001, 276, 251-260. [CrossRef] [PubMed]

149. Lee, M.J.; Kim, M.Y.; Mo, J.S.; Ann, E.J.; Seo, M.S.; Hong, J.A.; Kim, Y.C.; Park, H.S. Indirubin-3'-monoxime, a derivative of a Chinese anti-leukemia medicine, inhibits Notch1 signaling. Cancer Lett. 2008, 265, 215-225. [CrossRef]

150. Gonzalez Arbelaez, L.F.; Perez Nunez, I.A.; Mosca, S.M. Gsk-3beta inhibitors mimic the cardioprotection mediated by ischemic pre- and postconditioning in hypertensive rats. BioMed Res. Int. 2013, 2013, 317456. [CrossRef]

151. Wang, Y.; Hoi, P.M.; Chan, J.Y.; Lee, S.M. New perspective on the dual functions of indirubins in cancer therapy and neuroprotection. Anti-Cancer Agents Med. Chem. 2014, 14, 1213-1219. [CrossRef]

152. Zhang, N.; Zhong, R.; Yan, H.; Jiang, Y. Structural features underlying selective inhibition of GSK3beta by dibromocantharelline: Implications for rational drug design. Chem. Biol. Drug Des. 2011, 77, 199-205. [CrossRef]

153. Kramer, T.; Schmidt, B.; Lo Monte, F. Small-Molecule Inhibitors of GSK-3: Structural Insights and Their Application to Alzheimer's Disease Models. Int. J. Alzheimer Dis. 2012, 2012, 381029. [CrossRef]

154. Meijer, L.; Thunnissen, A.M.; White, A.W.; Garnier, M.; Nikolic, M.; Tsai, L.H.; Walter, J.; Cleverley, K.E.; Salinas, P.C.; Wu, Y.Z.; et al. Inhibition of cyclin-dependent kinases, GSK-3beta and CK1 by hymenialdisine, a marine sponge constituent. Chem. Biol. 2000, 7, 51-63. [CrossRef]

155. Wang, Q.; Chen, D.; Jin, H.; Ye, Z.; Wang, C.; Chen, K.; Kuek, V.; Xu, K.; Qiu, H.; Chen, P.; et al. Hymenialdisine: A Marine Natural Product That Acts on Both Osteoblasts and Osteoclasts and Prevents Estrogen-Dependent Bone Loss in Mice. J. Bone Miner. Res. Off. J. Am. Soc. Bone Miner. Res. 2020, 35, 1582-1596. [CrossRef] [PubMed]

156. Kalinichev, M.; Dawson, L.A. Evidence for antimanic efficacy of glycogen synthase kinase-3 (GSK3) inhibitors in a strain-specific model of acute mania. Int. J. Neuropsychopharmacol. 2011, 14, 1051-1067. [CrossRef]

157. Tatebayashi, Y.; Haque, N.; Tung, Y.C.; Iqbal, K.; Grundke-Iqbal, I. Role of tau phosphorylation by glycogen synthase kinase-3beta in the regulation of organelle transport. J. Cell Sci. 2004, 117, 1653-1663. [CrossRef] 
158. Cui, C.; Wang, Y.; Wang, Y.; Zhao, M.; Peng, S. Alsterpaullone, a Cyclin-Dependent Kinase Inhibitor, Mediated Toxicity in HeLa Cells through Apoptosis-Inducing Effect. J. Anal. Methods Chem. 2013, 2013, 602091. [CrossRef]

159. Faria, C.C.; Agnihotri, S.; Mack, S.C.; Golbourn, B.J.; Diaz, R.J.; Olsen, S.; Bryant, M.; Bebenek, M.; Wang, X.; Bertrand, K.C.; et al. Identification of alsterpaullone as a novel small molecule inhibitor to target group 3 medulloblastoma. Oncotarget 2015, 6, 21718-21729. [CrossRef]

160. Watanabe, T.; Sato, Y.; Masud, H.; Takayama, M.; Matsuda, H.; Hara, Y.; Yanagi, Y.; Yoshida, M.; Goshima, F.; Murata, T.; et al. Antitumor activity of cyclin-dependent kinase inhibitor alsterpaullone in Epstein-Barr virus-associated lymphoproliferative disorders. Cancer Sci. 2020, 111, 279-287. [CrossRef] [PubMed]

161. Stukenbrock, H.; Mussmann, R.; Geese, M.; Ferandin, Y.; Lozach, O.; Lemcke, T.; Kegel, S.; Lomow, A.; Burk, U.; Dohrmann, C.; et al. 9-cyano-1-azapaullone (cazpaullone), a glycogen synthase kinase-3 (GSK-3) inhibitor activating pancreatic beta cell protection and replication. J. Med. Chem. 2008, 51, 2196-2207. [CrossRef]

162. Zaharevitz, D.W.; Gussio, R.; Leost, M.; Senderowicz, A.M.; Lahusen, T.; Kunick, C.; Meijer, L.; Sausville, E.A. Discovery and initial characterization of the paullones, a novel class of small-molecule inhibitors of cyclin-dependent kinases. Cancer Res. 1999, 59, 2566-2569.

163. Yoshida, H.; Kotani, H.; Kondo, T.; Tani, I.; Wei, X.; Tsuruta, S.; Kimura, A.; Asakawa, M.; Ito, M.; Nagai, S.; et al. CDK inhibitors suppress Th17 and promote iTreg differentiation, and ameliorate experimental autoimmune encephalomyelitis in mice. Biochem. Biophys. Res. Commun. 2013, 435, 378-384. [CrossRef]

164. Joo, H.C.; Choi, J.W.; Moon, H.; Lee, C.Y.; Yoo, K.J.; Kim, S.W.; Hwang, K.C. Protective effects of kenpaullone on cardiomyocytes following H2O2-induced oxidative stress are attributed to inhibition of connexin 43 degradation by SGSM3. Biochem. Biophys. Res. Commun. 2018, 499, 368-373. [CrossRef]

165. Kitabayashi, T.; Dong, Y.; Furuta, T.; Sabit, H.; Jiapaer, S.; Zhang, J.; Zhang, G.; Hayashi, Y.; Kobayashi, M.; Domoto, T.; et al. Identification of GSK3beta inhibitor kenpaullone as a temozolomide enhancer against glioblastoma. Sci. Rep. 2019, 9, 10049. [CrossRef] [PubMed]

166. Martins, D.F.; Rosa, A.O.; Gadotti, V.M.; Mazzardo-Martins, L.; Nascimento, F.P.; Egea, J.; Lopez, M.G.; Santos, A.R. The antinociceptive effects of AR-A014418, a selective inhibitor of glycogen synthase kinase-3 beta, in mice. J. Pain 2011, 12, 315-322. [CrossRef]

167. Koh, S.H.; Kim, Y.; Kim, H.Y.; Hwang, S.; Lee, C.H.; Kim, S.H. Inhibition of glycogen synthase kinase-3 suppresses the onset of symptoms and disease progression of G93A-SOD1 mouse model of ALS. Exp. Neurol. 2007, 205, 336-346. [CrossRef]

168. Bhat, R.; Xue, Y.; Berg, S.; Hellberg, S.; Ormo, M.; Nilsson, Y.; Radesater, A.C.; Jerning, E.; Markgren, P.O.; Borgegard, T.; et al. Structural insights and biological effects of glycogen synthase kinase 3-specific inhibitor AR-A014418. J. Biol. Chem. 2003, 278, 45937-45945. [CrossRef]

169. Georgievska, B.; Sandin, J.; Doherty, J.; Mortberg, A.; Neelissen, J.; Andersson, A.; Gruber, S.; Nilsson, Y.; Schott, P.; Arvidsson, P.I.; et al. AZD1080, a novel GSK3 inhibitor, rescues synaptic plasticity deficits in rodent brain and exhibits peripheral target engagement in humans. J. Neurochem. 2013, 125, 446-456. [CrossRef]

170. Eldar-Finkelman, H.; Martinez, A. GSK-3 Inhibitors: Preclinical and Clinical Focus on CNS. Front. Mol. Neurosci. $2011,4,32$. [CrossRef] [PubMed]

171. Bidon-Chanal, A.; Fuertes, A.; Alonso, D.; Perez, D.I.; Martinez, A.; Luque, F.J.; Medina, M. Evidence for a new binding mode to GSK-3: Allosteric regulation by the marine compound palinurin. Eur. J. Med. Chem. 2013, 60, 479-489. [CrossRef] [PubMed]

172. Perez, D.I.; Conde, S.; Perez, C.; Gil, C.; Simon, D.; Wandosell, F.; Moreno, F.J.; Gelpi, J.L.; Luque, F.J.; Martinez, A. Thienylhalomethylketones: Irreversible glycogen synthase kinase 3 inhibitors as useful pharmacological tools. Bioorganic Med. Chem. 2009, 17, 6914-6925. [CrossRef]

173. Rosa, A.O.; Egea, J.; Martinez, A.; Garcia, A.G.; Lopez, M.G. Neuroprotective effect of the new thiadiazolidinone NP00111 against oxygen-glucose deprivation in rat hippocampal slices: Implication of ERK1/2 and PPARgamma receptors. Exp. Neurol. 2008, 212, 93-99. [CrossRef]

174. Luna-Medina, R.; Cortes-Canteli, M.; Alonso, M.; Santos, A.; Martinez, A.; Perez-Castillo, A. Regulation of inflammatory response in neural cells in vitro by thiadiazolidinones derivatives through peroxisome proliferator-activated receptor gamma activation. J. Biol. Chem. 2005, 280, 21453-21462. [CrossRef]

175. Rosa, A.O.; Kaster, M.P.; Binfare, R.W.; Morales, S.; Martin-Aparicio, E.; Navarro-Rico, M.L.; Martinez, A.; Medina, M.; Garcia, A.G.; Lopez, M.G.; et al. Antidepressant-like effect of the novel thiadiazolidinone NP031115 in mice. Prog. Neuro-Psychopharmacol. Biol. Psychiatry 2008, 32, 1549-1556. [CrossRef]

176. Dominguez, J.M.; Fuertes, A.; Orozco, L.; del Monte-Millan, M.; Delgado, E.; Medina, M. Evidence for irreversible inhibition of glycogen synthase kinase-3beta by tideglusib. J. Biol. Chem. 2012, 287, 893-904. [CrossRef] [PubMed]

177. Sereno, L.; Coma, M.; Rodriguez, M.; Sanchez-Ferrer, P.; Sanchez, M.B.; Gich, I.; Agullo, J.M.; Perez, M.; Avila, J.; GuardiaLaguarta, C.; et al. A novel GSK-3beta inhibitor reduces Alzheimer's pathology and rescues neuronal loss in vivo. Neurobiol. Dis. 2009, 35, 359-367. [CrossRef]

178. Luna-Medina, R.; Cortes-Canteli, M.; Sanchez-Galiano, S.; Morales-Garcia, J.A.; Martinez, A.; Santos, A.; Perez-Castillo, A. NP031112, a thiadiazolidinone compound, prevents inflammation and neurodegeneration under excitotoxic conditions: Potential therapeutic role in brain disorders. J. Neurosci. Off. J. Soc. Neurosci. 2007, 27, 5766-5776. [CrossRef] [PubMed] 
179. Guzman, M.L.; Li, X.; Corbett, C.A.; Rossi, R.M.; Bushnell, T.; Liesveld, J.L.; Hebert, J.; Young, F.; Jordan, C.T. Rapid and selective death of leukemia stem and progenitor cells induced by the compound 4-benzyl, 2-methyl, 1,2,4-thiadiazolidine, 3,5 dione (TDZD-8). Blood 2007, 110, 4436-4444. [CrossRef] [PubMed]

180. Martinez, A.; Alonso, M.; Castro, A.; Perez, C.; Moreno, F.J. First non-ATP competitive glycogen synthase kinase 3 beta (GSK3beta) inhibitors: Thiadiazolidinones (TDZD) as potential drugs for the treatment of Alzheimer's disease. J. Med. Chem. 2002, 45, 1292-1299. [CrossRef] [PubMed]

181. Hamann, M.; Alonso, D.; Martin-Aparicio, E.; Fuertes, A.; Perez-Puerto, M.J.; Castro, A.; Morales, S.; Navarro, M.L.; Del Monte-Millan, M.; Medina, M.; et al. Glycogen synthase kinase-3 (GSK-3) inhibitory activity and structure-activity relationship (SAR) studies of the manzamine alkaloids. Potential for Alzheimer's disease. J. Nat. Prod. 2007, 70, 1397-1405. [CrossRef]

182. Radwan, M.; Hanora, A.; Khalifa, S.; Abou-El-Ela, S.H. Manzamines: A potential for novel cures. Cell Cycle 2012, 11, 1765-1772. [CrossRef] [PubMed]

183. Kaidanovich-Beilin, O.; Milman, A.; Weizman, A.; Pick, C.G.; Eldar-Finkelman, H. Rapid antidepressive-like activity of specific glycogen synthase kinase-3 inhibitor and its effect on beta-catenin in mouse hippocampus. Biol. Psychiatry 2004, 55, 781-784 [CrossRef]

184. Chen, G.; Bower, K.A.; Ma, C.; Fang, S.; Thiele, C.J.; Luo, J. Glycogen synthase kinase 3beta (GSK3beta) mediates 6hydroxydopamine-induced neuronal death. FASEB J. Off. Publ. Fed. Am. Soc. Exp. Biol. 2004, 18, 1162-1164. [CrossRef]

185. Kaidanovich-Beilin, O.; Eldar-Finkelman, H. Long-term treatment with novel glycogen synthase kinase-3 inhibitor improves glucose homeostasis in ob/ob mice: Molecular characterization in liver and muscle. J. Pharmacol. Exp. Ther. 2006, 316, 17-24. [CrossRef]

186. Avrahami, L.; Farfara, D.; Shaham-Kol, M.; Vassar, R.; Frenkel, D.; Eldar-Finkelman, H. Inhibition of glycogen synthase kinase-3 ameliorates beta-amyloid pathology and restores lysosomal acidification and mammalian target of rapamycin activity in the Alzheimer disease mouse model: In vivo and in vitro studies. J. Biol. Chem. 2013, 288, 1295-1306. [CrossRef]

187. Beurel, E.; Kaidanovich-Beilin, O.; Yeh, W.I.; Song, L.; Palomo, V.; Michalek, S.M.; Woodgett, J.R.; Harrington, L.E.; EldarFinkelman, H.; Martinez, A.; et al. Regulation of Th1 cells and experimental autoimmune encephalomyelitis by glycogen synthase kinase-3. J. Immunol. 2013, 190, 5000-5011. [CrossRef]

188. Rippin, I.; Bonder, K.; Joseph, S.; Sarsor, A.; Vaks, L.; Eldar-Finkelman, H. Inhibition of GSK-3 ameliorates the pathogenesis of Huntington's disease. Neurobiol. Dis. 2021, 154, 105336. [CrossRef] [PubMed]

189. Licht-Murava, A.; Paz, R.; Vaks, L.; Avrahami, L.; Plotkin, B.; Eisenstein, M.; Eldar-Finkelman, H. A unique type of GSK-3 inhibitor brings new opportunities to the clinic. Sci. Signal. 2016, 9, ra110. [CrossRef]

190. Motawi, T.M.; Bustanji, Y.; El-Maraghy, S.A.; Taha, M.O.; Al Ghussein, M.A. Naproxen and cromolyn as new glycogen synthase kinase 3beta inhibitors for amelioration of diabetes and obesity: An investigation by docking simulation and subsequent in vitro/in vivo biochemical evaluation. J. Biochem. Mol. Toxicol. 2013, 27, 425-436. [CrossRef]

191. Alhusaini, A.; Fadda, L.; Hasan, I.H.; Zakaria, E.; Alenazi, A.M.; Mahmoud, A.M. Curcumin Ameliorates Lead-Induced Hepatotoxicity by Suppressing Oxidative Stress and Inflammation, and Modulating Akt/GSK-3beta Signaling Pathway. Biomolecules 2019, 9, 703. [CrossRef]

192. McCubrey, J.A.; Lertpiriyapong, K.; Steelman, L.S.; Abrams, S.L.; Cocco, L.; Ratti, S.; Martelli, A.M.; Candido, S.; Libra, M.; Montalto, G.; et al. Regulation of GSK-3 activity by curcumin, berberine and resveratrol: Potential effects on multiple diseases. Adv. Biol. Regul. 2017, 65, 77-88. [CrossRef]

193. Jeong, C.W.; Yoo, K.Y.; Lee, S.H.; Jeong, H.J.; Lee, C.S.; Kim, S.J. Curcumin protects against regional myocardial ischemia/reperfusion injury through activation of RISK/GSK-3beta and inhibition of p38 MAPK and JNK. J. Cardiovasc. Pharmacol. Ther. 2012, 17, 387-394. [CrossRef]

194. Yu, W.; Wu, J.; Cai, F.; Xiang, J.; Zha, W.; Fan, D.; Guo, S.; Ming, Z.; Liu, C. Curcumin alleviates diabetic cardiomyopathy in experimental diabetic rats. PLoS ONE 2012, 7, e52013. [CrossRef] [PubMed]

195. Huang, H.C.; Xu, K.; Jiang, Z.F. Curcumin-mediated neuroprotection against amyloid-beta-induced mitochondrial dysfunction involves the inhibition of GSK-3beta. J. Alzheimer Dis. JAD 2012, 32, 981-996. [CrossRef]

196. Xiong, Z.; Hongmei, Z.; Lu, S.; Yu, L. Curcumin mediates presenilin-1 activity to reduce beta-amyloid production in a model of Alzheimer's Disease. Pharmacol. Rep. PR 2011, 63, 1101-1108. [CrossRef]

197. Bustanji, Y.; Taha, M.O.; Almasri, I.M.; Al-Ghussein, M.A.; Mohammad, M.K.; Alkhatib, H.S. Inhibition of glycogen synthase kinase by curcumin: Investigation by simulated molecular docking and subsequent in vitro/in vivo evaluation. J. Enzym. Inhib. Med. Chem. 2009, 24, 771-778. [CrossRef]

198. Mohammad, M.; Al-Masri, I.M.; Issa, A.; Al-Ghussein, M.A.; Fararjeh, M.; Alkhatib, H.; Taha, M.O.; Bustanji, Y. Famotidine inhibits glycogen synthase kinase-3beta: An investigation by docking simulation and experimental validation. J. Enzym. Inhib. Med. Chem. 2013, 28, 690-694. [CrossRef]

199. Unal, G.; Dokumaci, A.H.; Ozkartal, C.S.; Yerer, M.B.; Aricioglu, F. Famotidine has a neuroprotective effect on MK-801 induced toxicity via the Akt/GSK-3beta/beta-catenin signaling pathway in the SH-SY5Y cell line. Chem.-Biol. Interact. 2019, $314,108823$. [CrossRef] [PubMed]

200. Beurel, E.; Jope, R.S. Inflammation and lithium: Clues to mechanisms contributing to suicide-linked traits. Transl. Psychiatry 2014, 4, e488. [CrossRef] 
201. Won, E.; Kim, Y.K. An Oldie but Goodie: Lithium in the Treatment of Bipolar Disorder through Neuroprotective and Neurotrophic Mechanisms. Int. J. Mol. Sci. 2017, 18, 2679. [CrossRef] [PubMed]

202. Morlet, E.; Hozer, F.; Costemale-Lacoste, J.F. Neuroprotective effects of lithium: What are the implications in humans with neurodegenerative disorders? Geriatr. Et Psychol. Neuropsychiatr. Du Vieil. 2018, 16, 78-86. [CrossRef] [PubMed]

203. Hampel, H.; Lista, S.; Mango, D.; Nistico, R.; Perry, G.; Avila, J.; Hernandez, F.; Geerts, H.; Vergallo, A.; Alzheimer Precision Medicine, I. Lithium as a Treatment for Alzheimer's Disease: The Systems Pharmacology Perspective. J. Alzheimer Dis. JAD 2019, 69, 615-629. [CrossRef] [PubMed]

204. Snitow, M.E.; Bhansali, R.S.; Klein, P.S. Lithium and Therapeutic Targeting of GSK-3. Cells 2021, 10, 255. [CrossRef]

205. Mohammad, M.K.; Al-Masri, I.M.; Taha, M.O.; Al-Ghussein, M.A.; Alkhatib, H.S.; Najjar, S.; Bustanji, Y. Olanzapine inhibits glycogen synthase kinase-3beta: An investigation by docking simulation and experimental validation. Eur. J. Pharmacol. 2008, 584, 185-191. [CrossRef] [PubMed]

206. Li, X.; Rosborough, K.M.; Friedman, A.B.; Zhu, W.; Roth, K.A. Regulation of mouse brain glycogen synthase kinase-3 by atypical antipsychotics. Int. J. Neuropsychopharmacol. 2007, 10, 7-19. [CrossRef]

207. Li, X.; Liu, M.; Cai, Z.; Wang, G.; Li, X. Regulation of glycogen synthase kinase-3 during bipolar mania treatment. Bipolar Disord. 2010, 12, 741-752. [CrossRef] [PubMed]

208. Ilouz, R.; Kaidanovich, O.; Gurwitz, D.; Eldar-Finkelman, H. Inhibition of glycogen synthase kinase-3beta by bivalent zinc ions: Insight into the insulin-mimetic action of zinc. Biochem. Biophys. Res. Commun. 2002, 295, 102-106. [CrossRef]

209. Szewczyk, B.; Poleszak, E.; Sowa-Kucma, M.; Siwek, M.; Dudek, D.; Ryszewska-Pokrasniewicz, B.; Radziwon-Zaleska, M.; Opoka, W.; Czekaj, J.; Pilc, A.; et al. Antidepressant activity of zinc and magnesium in view of the current hypotheses of antidepressant action. Pharmacol. Rep. PR 2008, 60, 588-589.

210. Chanoit, G.; Lee, S.; Xi, J.; Zhu, M.; McIntosh, R.A.; Mueller, R.A.; Norfleet, E.A.; Xu, Z. Exogenous zinc protects cardiac cells from reperfusion injury by targeting mitochondrial permeability transition pore through inactivation of glycogen synthase kinase-3beta. Am. J. Physiol. Heart Circ. Physiol. 2008, 295, H1227-H1233. [CrossRef]

211. Stelmashook, E.V.; Isaev, N.K.; Genrikhs, E.E.; Amelkina, G.A.; Khaspekov, L.G.; Skrebitsky, V.G.; Illarioshkin, S.N. Role of zinc and copper ions in the pathogenetic mechanisms of Alzheimer's and Parkinson's diseases. Biochemistry. Biokhimiia 2014, 79, 391-396. [CrossRef] 